
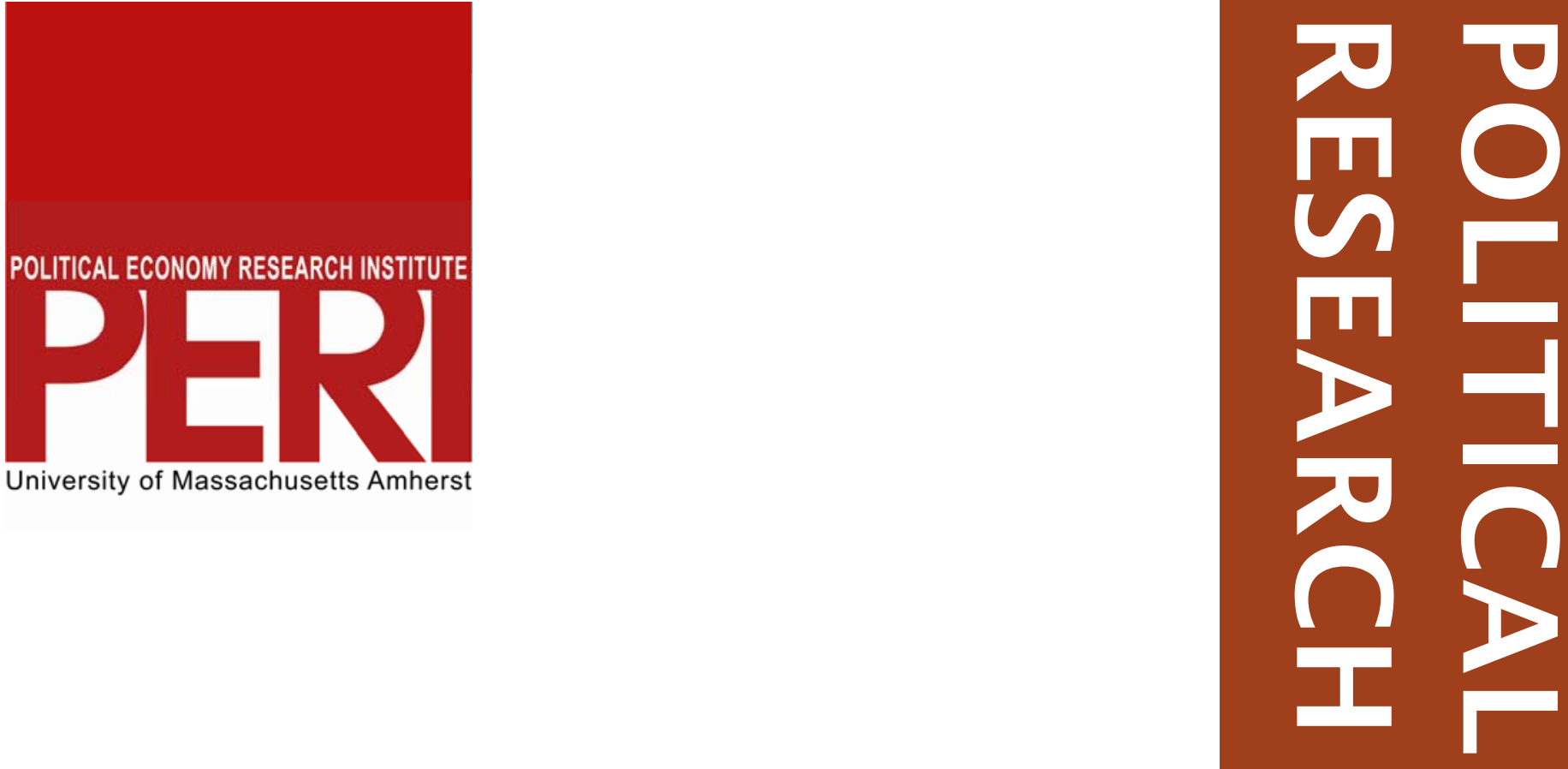

Have Differences in Credit Access Diminished in an Era of Financial Market Deregulation?

\author{
Christian E. Weller
}

August 2007

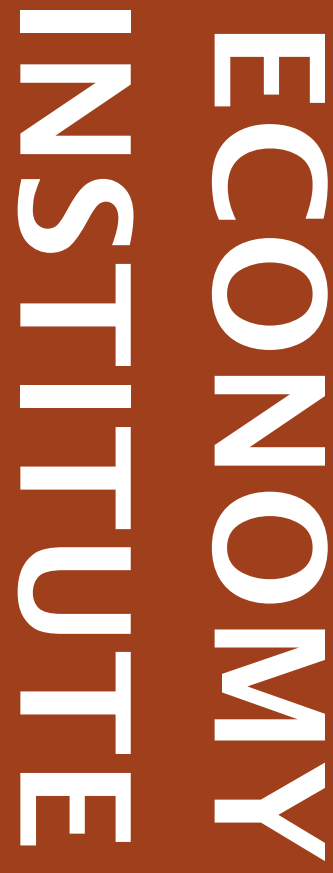

Gordon Hall

418 North Pleasant Street

Amherst, MA 01002

Phone: 413.545 .6355

Fax: 413.577 .0261

peri@econs.umass.edu www.peri.umass.edu 


\title{
Have Differences in Credit Access Diminished in an Era of Financial Market Deregulation?
}

\author{
Christian E. Weller \\ Associate Professor \\ Department of Public Policy and Public Affairs \\ University of Massachusetts Boston \\ 100 Morrissey Boulevard \\ Boston, MA 02125 \\ and \\ Senior Fellow \\ Center for American Progress \\ 1333 H Street NW \\ Washington, DC 20005 \\ cweller@americanprogress.org \\ (202) 741-6367
}

\begin{abstract}
Over the past few decades, financial markets became increasingly deregulated and household debt expanded, sometimes rapidly. It is thus possible that greater deregulation led to improved credit access for typically underserved groups, such as minorities and low-income families, relative to their counterparts. Credit access is measured here by loan denials, discouraged applications, and costs of credit. Based on data from the Federal Reserve's Survey Consumer Finances and using multivariate tests, there is no clear trend, though, towards equalization of credit access from 1989 to 2004. Specifically, gaps in loan denials and discouraged applications only improved for Hispanics relative to Whites. Also, the gap in interest rates widened from 1989 to 2004 by race and income, while Hispanics possibly faced a growing difference in fees relative to Whites. Finally, by 2004, the gap in reliance on more costly sources of credit had shrunk slightly between minorities and lower-income families because the relative differences in borrowing from more expensive sources narrowed. Also, by 2004, lower-income families and minorities depended on more costly forms of credit more so than their counterparts to the same degree as they did in 1989. The results indicate that differences in credit access did not decrease on a broad basis during a period of large scale financial deregulation.
\end{abstract}

Keywords: Household debt; credit access; costs of debt; interest rates; financial deregulation 


\section{Introduction}

Household credit can be a conduit for economic mobility and stability. Most families need to borrow money to invest in a home, their education, or their own business. Families also borrow to smooth out income fluctuations.

Yet, not all families traditionally had equal access to credit. In particular, low-income families and minorities often had less credit access than their counterparts.

Credit access, though, also encompasses the costs of credit. Traditionally, low-income families and minorities found themselves burdened with more costly forms of credit.

Past studies indicate that differences in credit access and the costs of credit persisted against the backdrop of sweeping changes in the U.S. financial system over the past few decades. Although financial market deregulation was intended to increase competition, the results were greater financial market consolidation with ambiguous results for underserved borrowers. Fewer banks may mean fewer services, but larger banks may be better able to take advantage of economies of scale. Moreover, offsetting the potentially adverse effects of financial market consolidation was possibly more widespread financial product competition, e.g. through the use of information technology.

In this paper, I consider if low-income and minority borrowers experienced improved credit market access, both in terms of credit constraints and costs of credit, since 1989. Specifically, I consider both differences in credit constraints and differences in the costs of loans over time.

The rest of the paper is structured as follows. Section II reviews the relevant literature. In section III, some descriptive statistics are presented. Section IV presents multivariate tests for differences in credit access between groups and over time. Concluding remarks follow in section $\mathrm{V}$.

\section{Literature Review}

Debt allows families to invest in a home or their education. The biggest reason for families to go into debt is for a home, either its purchase or its expansion and renovation (Weller and Douglas, 2007). Other investment loans are loans for investment properties, education loans, and car loans. ${ }^{1}$

By borrowing families can also master short-term income fluctuations. With debt, families can still pay for most of their basic needs, even if their income temporarily drops (Bloemen \& Stancanelli, 2005; Krueger and Perri, 2002, 2005).

As is well established, credit is often rationed (Stiglitz and Weiss, 1981). Credit rationing tends to vary by a number of variables, which can include personal characteristics of the borrower, such as family size, marital status, living arrangements, but also race and

\footnotetext{
${ }^{1}$ The vast majority of people, $79 \%$ in 2005 , drove themselves to work, according to the Census (2006).
} 
ethnicity. A number of studies have, for instance, documented that loan denial rates vary by race, so that non-whites tend to have higher loan denial rates than whites, even after controlling for other relevant characteristics (Blanchflower et al., 2003; Canner et al., 1994; Cavalluzzo and Wolken, 2005; Dymski, 2001; Gabriel \& Rosenthal, 1991; Holloway \& Wyly, 2001; Munnell, et al., 1996; Ross, 2005). Crook (1996) found that, in addition to race, income and age matter, with lower-income and older families being less likely to see their loan applications being denied. Additional reasons for loan denials included financial characteristics, such as credit history, income, and wealth. Also, a credit application may be denied because of issues associated with a loan, e.g. a lender may be prohibited from making a particular loan. And finally, there are reasons specific to a lender for denying credit, e.g. a requirement to have had a past banking relationship with a lender (Chakravarty, 2002).

Importantly, credit access is not only a question of getting a loan application approved, but also a question of the conditions of a loan. Very high cost loans include payday lending, car title loans, and overdraft loans (CU, 2003; James \& Smith, 2006). For instance, interest rates on payday loans average typically about $400 \%$ (CRL, 2006). Fox and Guy (2005) also estimated that the median annual interest rate for a car title loan is about 300\% and Duby et al. (2005) argued that overdraft fees can quickly translate into triple-digit annualized interest rates.

Minorities and lower-income families tend to disproportionately depend on higher-cost loans (Barr, 2001; CFA, 1998, 1999; Stegman \& Faris, 2003). For example, payday lenders seem to target African-American families, low-income families, and military families (CRL, 2005; DOD, 2006; Graves \& Peterson, 2005; Tanik , 2005). Also, repeat users of overdraft loans seem to be more likely than not to be lower-income and nonwhite (James \& Smith, 2006). And, car title loans seem to be more prevalent among lower-income families and military families than among others (Fox \& Guy, 2005).

Credit card debt, which has expanded among previously underserved groups, is another form of credit that tends to have above average costs associated with it (Manning, 2000). Credit card debt tends to be comparatively costly since credit card balances often not only incur interest that is higher than other forms of credit, e.g. mortgages, but also result in borrowers being charged a number of additional fees (Westrich and Bush, 2005).

Again, credit card debt is relatively more prevalent among lower-income and minority families than among their families (Bird et al., 1998; Black \& Morgan, 1999; Manning, 2000; Yoo, 1996). Moreover, the terms and conditions of credit cards tend to be worse for low-income families than for higher-income ones (Ausubel, 1999; Stavins, 2000).

Finally, subprime mortgages, which tend to be more costly than prime mortgages, tend to be directed to a disproportionate degree towards minority and low-income borrowers. Importantly, minority borrowers are more likely to receive a subprime mortgage than their similarly situated counter parts (Bocian et al., 2006; Fishbein and Woodall, 2006). 
In addition, the cost of debt can vary based on the lending institution, since credit markets tend to be segmented. For one, lenders build on their experience with particular groups of borrowers and tailor their products to them. Second, borrowers do not have the necessary resources to collect and digest all of the necessary financial information, thereby allowing niche markets to be created. More financial education would allow families to build wealth on better terms (Fox \& Hoffman, 2004; Hilgert et al. 2003; Weinberg, 2006), with particular benefits for minorities and low-income families (Choudhury, 2002; Finke et al., 2005; Lyons \& Scherpf, 2004; Lyons, Chang \& Scherpf, 2006; Lyons et al., 2006; Schug et al., 2006; Yao et al., 2005). Also, regulatory restrictions, such as limits on credit union activities, can lead to market segmentation. ${ }^{2}$ Lastly, lenders will limit the geographic scope of their activities based on limited resources or discriminatory practices, such as red-lining (Munnell et al., 1996; Newman \& Wyly, 2004; Wyly \& Hammel, 2004).

A number of important financial market changes, though, may have contributed to growing credit access for all borrowers, especially low-income and minority ones. Greater deregulation in the U.S. financial markets led to greater profitability and less risky loan portfolios of banks, which may have laid the foundation for banks offering more banking services to previously underserved borrowers. The U.S. financial market has become deregulated since the early 1990s, when interstate banking prohibitions were ended in 1994 and limits on financial service cross-shareholdings were reduced with the passage of the Gramm-Leach-Bliley Financial Services Modernization Act of 1999. Greater deregulation resulted in a wave of merger and acquisition activities and consolidation in the financial services industry (Rhoades, 2000; Wheelock \& Wilson, 2004). Evaluations of the wave of bank consolidations generally found that banks became more profitable and their loan portfolios less risky (Akhigbe \& Madura, 2004; Akhigbe et al., 2004; Al Mamun et al., 2005; Yildirim et al., 2006).

On the other hand, concerns have been voiced about the impact on communities that greater consolidation may ultimately lead to fewer services for already underserved communities. An often studied example is the access of small businesses to bank credit, which may serve as a bellwether for credit access for other communities, such as minorities and low-income ones. The limited empirical evidence suggests that small business access to credit did not shrink in the wake of financial service consolidation over the past two decades (Avery \& Samolyk, 2004; Cavalluzzo et al., 2002; Carow et al., 2006; Hein et al., 2005; Rauch \& Hendrickson, 2004; Rose 1993).

It is possible that potential adverse effects from financial market consolidation may have been offset by other factors. For instance, new technologies seem to have proliferated, resulting in more credit access for vulnerable groups, such as small businesses (Berger,

\footnotetext{
${ }^{2}$ Limitations on credit unions' scope and activities with respect to personal finance have decreased over time. For instance, in the 1980s, credit unions were permitted to offer first mortgages and in the late 1990s, credit unions have been allowed to offer membership to multiple groups (Leggett and Strand, 2002; Tripp \& Smith, 1993). Following the greater scope of credit unions, they have experienced strong growth (Goddard et al., 2002; Kaushik \& Lopez, 1994). Even if families are not credit union members, they may be able to enjoy the benefits of this strong growth since the competition with credit unions seems to have lowered the costs of financial services at banks that directly compete with credit unions (Emmons \& Schmid, 2000; Feinberg, 2001; Feinberg \& Rahman, 2001).
} 
2003; Ely \& Robinson, 2001; White, 2002). In addition, regulatory tools, in particular the Community Reinvestment Act, may have helped to offset trends towards declining credit access for underserved borrowers (Bostic et al., 2002). Similar policies include a proliferation of loan programs targeted at underserved borrowers (Bates, 2000).

Consequently, in the wake of deregulation, consolidation, technological improvements, and new policy measures over the past two decades, access to credit, particularly for minority borrowers, should have improved. Cavalluzzo and Cavalluzzo (1998), for instance, found that differences in credit constraints and the costs of capital are smaller in markets, where banking concentration is lower. Also, Dymski (2001) found that the difference in racial inequality persisted, but has been declining in many U.S. cities between 1992 and 1998. Finally, Lyons (2003) argued that between 1992 and 1998 all families saw improved credit access with particularly strong improvements for black families and families with low earnings.

There are several hypotheses that emerge from the literature. First, minorities and lowincome families face more credit constraints, particularly they are more likely to have a loan application denied than their counterparts. Second, minorities and low-income borrowers face higher costs of debt than their counterparts. Third, the differences may have decreased over time in the wake of more financial market deregulation.

\section{Trends in credit access}

To analyze access to credit and the quality of credit, this paper relies on a household survey. The Federal Reserve produces a tri-annual data set, the Survey of Consumer Finances (SCF), which includes comprehensive information on household debt and assets. The SCF surveys a cross-section of the U.S. population every three years. The survey covers all forms of financial and non-financial assets as well as many forms of credit, such as credit card debt, mortgages, margin debt, loans against pension plans and life insurances, among others. The last available survey year is 2004. Consistent data for most variables are available since 1989. Because the interest of the survey is to get an accurate picture of financial assets and formal debt in the U.S., it tends to oversample high-income families. For the purposes of this analysis, this also implies that the SCF underreports debt from non-traditional lenders that are more prevalent among lowerincome borrowers.

\section{III.1 Loan denials and discouraged applications}

The discussion of credit access for different groups occurs against the backdrop of an unprecedented debt boom in the U.S. that started in 2001. The share of families with any debt increased from $75.1 \%$ in 2001 to $76.4 \%$ in 2004 , thus roughly continuing the trend towards more households with debt since 1989. The increase of the share of families with any debt was particularly pronounced among white families, low-income families, and families 65 and older (see Table 1).

** INSERT TABLE 1 ABOUT HERE** 
However, more important the growth in the share of families with debt was the total outstanding amount of debt. The families, who owed any debt, owed more of it, relative to income, than before. In particular, from 2001 to 2004, the median ratio of total debt to income for families with any debt rose from $77 \%$ to $107 \%$, after rising more gradually from 52\% in 1989 (Weller \& Douglas, 2007). Thus, 2004 was the first year on record that the typical family owed more than it had in income, following accelerating in debt growth, relative to income, after 2001. The data thus show that the debt boom had probably more to do with a faster indebtedness of households that already had access to debt than with a broadening of credit access.

The question here is thus twofold. Did the increase in debt mean better access to credit for all families or did differences by demographic characteristics persist? Second, even if getting credit became easier, did differences in the cost of credit, if they existed to begin with, remain intact over time?

A first indication of credit access is whether a family has been denied an application for a loan. Here, a borrower is considered to have been denied credit if he or she applied for credit, was turned down and could not secure the full amount afterwards.

The share of loan denials was stable over time. In 2004, the share of families with loan denials was 13.0\%, up from 11.6\% in 1989 and from 12.3\% in 2001 (sees Table 2). ${ }^{3}$ There is no sign that loan denial rates declined over the years.

As expected, loan denial rates vary by race, ethnicity, and income. The denial rate for African-Americans in 2004 was about twice as large as that for white families, $22.0 \%$ as compared to $10.8 \%$ (see Table 2). In addition, families with incomes in the top fifth of the income distribution had denial rates of $4.5 \%$ in 2004 , compared to $15.7 \%$ for families in the middle quintile.

There is no clear sign that denial rates declined over time. On the contrary, for almost all groups, loan denial rates were higher in 2004 than in 1989 and in 2001. In addition, differences in denial rates widened by income - families in the top $40 \%$ of the income distribution over time had increasingly lower denial rates than other families - by race, and narrowed between Hispanics and Whites.

\section{** INSERT TABLE 2 ABOUT HERE **}

The discussion so far, though, ignores the possibility that some families felt discouraged from applying for a loan since they expected to be turned down anyway. If credit access increases, the share of families, who feel discouraged, should decline. The SCF asks families if they thought about applying for a loan in the previous five years, but did not do so because they thought they would be turned down.

\footnotetext{
${ }^{3}$ The years 1989 and 2001 are chosen as reference points since they are the closest data years to the last two business cycle peaks.
} 
The figures show that for most families, the share of families who felt discouraged from applying for a loan either remained constant or increased. ${ }^{4}$ For the population as a whole, $6.9 \%$ felt discouraged from applying for a loan in 2004, marginally down from $7.0 \%$ in 2001 and up from 5.5\% in 1989 (see Table 2).

Just as with denial rates, the share of discouraged families varied by demographics. Minorities were substantially more likely to feel discouraged from applying than whites and lower-income families tended to be more discouraged than higher-income ones. These gaps have either stayed constant or widened over time (see Table 2).

The figures indicate that the share of families with debt gradually increased over time, while at the same time, the share of families, who were credit constrained, either because they were denied credit or because they felt discouraged from applying, remained relatively stable between 1989 and 2004.

\section{III.2 Costs of credit}

The other aspect of credit access is the cost of credit. To approximate the cost of credit, the ratio of debt payments to outstanding debt is calculated. The sum of all debt payments captures a number of components of the costs of debt: interest, fees, and other payment terms. Debt payments are added for all forms of outstanding credit, i.e. the payment measure is in essence a weighted average across all loans. This makes it preferable to an interest rate measure, which only reflects one loan condition on the most recent loan.

Since the payment to debt ratio is a composite measure, there are several factors at play here. First, the composition of debt matters. For instance, mortgage debt tends to be lower cost than other forms of credit, for example, although it depends on the type of mortgage. Second, the source of debt matters, as particular lenders, especially finance companies and credit card lenders tend to offer higher cost loans. Third, payment conditions are included in the ratio of payments to debt. Some families may deliberately seek conditions, such as longer repayment periods, to reduce their monthly payments.

How important are payment conditions? One way to see people's choices for payment conditions is the share of ARMs since they initially offer lower payments. ${ }^{5,6}$ There is no systematic difference in the average share of ARMs out of total mortgages between whites, African-Americans, and Hispanics. ${ }^{7}$ If the shares of ARMs are an appropriate indicator for the likelihood of families to choose lower principal payments, all else equal, the debt payment to debt ratios presented here show differences in fees and interest rates by race and ethnicity. In comparison, the share of ARMs out of total mortgages was high for low-income and high-income families and lower in the middle of the income scale.

\footnotetext{
${ }^{4}$ To avoid double counting, only families who felt discouraged and were not denied credit are included here. See also Lyons (2003) for more details.

${ }^{5}$ The share of ARMs out of total mortgages is only used here as an indicator for a family's desire to have lower monthly payment options. It is not an argument that families with ARMs have higher fees.

${ }^{6}$ ARMs do not have universally lower cost. This is only true before interest rates reset to a fixed and presumably higher rate.

See Weller (2006) for details.
} 
This would suggest that differences in other costs, for instance, between low-income and middle-income families may be understated.

The median ratio of debt payments to debt declined over time. In 2004, the typical borrower had payments equal to $16.8 \%$ of their total debt, down from $28.2 \%$ in 1989 (see Table 3). The trend of declining payments per outstanding debt holds for all groups, but is most pronounced for African-Americans, middle income families, and families between the ages of 45 and 54. For instance, African-American borrowers paid 22.1\% of their debt in debt payments annually in 2004, down from 36.0\% in 1989.

Still, large differences remained. Minorities tended to pay more relative to their debt than whites and low-income families paid more than higher-income ones. In particular, African-Americans paid $22.1 \%$ of their debt in debt payments in 2004, compared to $19.7 \%$ for Hispanics, and $15.7 \%$ for whites.

*** INSERT TABLE 3 ABOUT HERE ***

One way to confirm that these payment differences reflect cost differences is to consider the interest rates charged for loans. ${ }^{8}$ Average interest rates tended to be higher for minorities than for whites and for low-income families than for higher-income ones (see Table 4). Also, the share of minorities and low-income and moderate-income families, who had very high interest on their debt, was greater than for their counterparts. For example, the share of African-Americans with mortgages that had interest rates that were at least $8 \%$ above the prime rate was $7.7 \%$ in 2004 , compared to $2.2 \%$ for Hispanics and only $0.9 \%$ for Whites. In addition, the share of Hispanics with credit card interest rates that were at least $8 \%$ above the prime was $53.1 \%$, compared to $47.3 \%$ for AfricanAmericans and $46.0 \%$ for Whites. A similar pattern exists for low-income and moderateincome families.

*** INSERT TABLE 4 ABOUT HERE ***

\section{III.3 Sources and types of loans}

Further, if financial market deregulation resulted in improved credit access, differences between borrowers with respect to the sources of credit and types of loans should have diminished.

The relatively higher debt payments of minorities may also reflect a larger share of loans from more costly sources, particularly installment loans. For instance, the average share of installment loans was $18.2 \%$ for African-Americans, but only $10.5 \%$ for whites and $10.9 \%$ for Hispanics (see Table 5). Also, families in the bottom fifth of the income distribution got $60.4 \%$ of their debt in mortgages, compared to $76.8 \%$ in the middle of the income distribution. At the same time, low-income families had one fourth of their debt

\footnotetext{
${ }^{8}$ This comparison is only suggestive of the cost differences since interest rates are only recorded for the most recent loan in a particular loan category and since this does not include fees and other non-interest costs of loans.
} 
in installment loans, compared to $13.5 \%$ for middle income families and $7.7 \%$ for families in the top fifth of the income distribution.

\section{*** INSERT TABLE 5 ABOUT HERE ***}

Finally, the sources of loans are considered. To simplify the discussion, financial institutions are combined into three categories: credit unions, traditional lenders, and consumer lenders. Traditional lenders comprise commercial banks, real estate lenders and savings and loans, while consumer lenders are credit card companies and finance companies.

Credit unions, which may offer lower-cost credit, account for only 3.6\% of all debt (see Table 6). White families had more credit from credit unions than non-whites families and middle-income families had more credit from credit unions than either low-income or high-income families. Further, traditional lenders were less important for AfricanAmericans and lower-income families than their counterparts. Finally, only minorities received a relatively large share of credit from consumer lenders.

\section{*** INSERT TABLE 6 ABOUT HERE ***}

The figures here suggest that minorities and low-income families still differed from their counterparts with respect to loan types and loan sources. In particular, low-income and minority families seemed to borrow more heavily from more costly loan sources and types.

\section{Testing for differences between groups and over time}

The figures so far suggest that minorities and low-income borrowers faced more credit constraints than their counterparts; that minorities and low-income borrowers paid more for their debt than whites and higher-income families; and that, despite years of financial market deregulation, minorities and low-income families still differed from their counterparts with respect to the sources and types of loans in 2004, so that borrowers and lower-income families still rely more heavily on more costly sources and types of loans.

\section{1 The differences in credit constraints between groups and over time}

To test if the differences in credit constraints are statistically significant between groups and over time, I perform three tests. First, a Cochran-Mantel-Haenszel (CMH) test is used to see if the probabilities of loan denials and discouraged applications depend on the year. The $\mathrm{CMH}$ test assumes a common odds ratio and tests, for instance, if the odds of being denied a loan for African-Americans is independent of the odds of being denied credit for Whites, after controlling for the time period.

Second, to test for the robustness of these results, a Breslow-Day (BD) test is performed to test the null hypothesis that the odds ratio is the same over time. 
Finally, a Mantel-Haenszel (MH) test is performed to see if the odds ratio for the respective demographic breakdown is statistically significantly different from one during all years. An odds ratio of greater than one would imply, for instance, that AfricanAmericans have a greater loan denial probability than Whites.

The tests are performed by race, ethnicity and income. They compare minorities to whites and all income groups to families in the top income quintile. To control for business cycle fluctuations, the tests compare the years closest to business cycle peaks: 1989, 2001, and 2004. As discussed before, it is tested if minorities and lower-income families faced more credit constraints than their counterparts and if those differences decreased over time.

The results are presented in table 7. To facilitate the presentation, “+” and "_“ indicate the size of the odds ratio and the change in the odds ratios. Specifically, for individual years "+” indicates that the odds of facing credit constraints are higher for minorities and lower-income families than for Whites and families in the top income quintile. For the comparison between years, “+” indicates more equal odds of credit constraints in 2004 than in either 1989 or 2001.

The MH test confirms that the differences by race, ethnicity and income are statistically significant. Specifically, minorities had a greater probability of loan denials and discouraged applications than Whites, and families in the top income quintile had a smaller chance of credit constraints than families in any of the other quintiles (Table 7).

\section{*** INSERT TABLE 7 ABOUT HERE ***}

Also, the difference in loan denials grew by race. For example, the $\mathrm{CMH}$ and $\mathrm{BD}$ tests reject the null hypothesis that the odds ratio of loan denials between African-Americans and Whites in 2004 were the same as in 1989, suggesting that the gap between AfricanAmericans and Whites in terms of loan denials widened over time. The same is true for the comparison between 2001 and 2004.

Similarly, Hispanic borrowers seem to faced a growing gap in loan denials relative to Whites in recent years. The differences in loan denials by ethnicity widened between 2001 and 2004, but not enough to completely erase the improvements in previous years, so that the odds ratio for loan denials between Hispanics and Whites was closer to one in 2004 than in 1989 (Table 7).

Finally, all income groups saw widening gaps in terms of loan denials relative to families in the top income quintile over time, regardless whether 2004 is compared to 2001 or to 1989 (Table 7).

The picture differs slightly for the probability of discouraged applications. For all groups, the gap narrowed between 2001 and 2004. It also narrowed between 1989 and 2004 by race and ethnicity, but not by income (Table 7). 
The differences in credit constraints by race and ethnicity may be a result of diverging income trends. To test for that possibility, $\mathrm{MH}$ tests are performed for each income quintile. The null hypothesis is that the odds of credit constraints for non-whites are equal to those of whites for the respective two year pairs, 1989 and 2004 and 2001 and 2004, in each income quintile.

The gap in credit constraints by race and ethnicity does not seem to be a result of income. The results show robustly that the odds of being credit constraint were larger for AfricanAmericans than for Whites, regardless of income (Table 8). For Hispanics, the odds of loan denials did not differ much between Hispanics and Whites among families in the bottom $40 \%$ of the income distribution, especially in 2001 and 2004. For higher-income Hispanic families, though, the odds of loan denials were clearly greater than those of whites. In addition, the odds of discouraged applications were generally higher for Hispanics than for whites. Still, Hispanic families, regardless of income, had a greater chance of being credit constrained than white families (Table 8).

*** INSERT TABLE 8 ABOUT HERE ***

\section{IV.2 The differences in costs of credit between groups and over time}

Next, I test if minorities and lower-income families had statistically significantly higher costs for their debt than their counterparts and if those differences changed over time. As was done before, comparisons between groups are tested for the years 1989, 2001 and 2004, while changes in the differences are tested relative to 2004. Here “+” for individual years indicates that minorities or lower-income families have higher debt payments relative to their counterparts. For comparisons between years, "-“ indicates a widening gap, while “+” indicates a narrowing gap.

The results indicate that minority families often had higher debt payments relative to their outstanding debt than white families, especially in 2001 and 2004 (Table 9). Also, lowerincome families, except those in the fourth quintile, had higher debt payments than families in the top income, regardless of the year under investigation.

The difference in the costs of credit declined for several groups between 1989 and 2004. African-Americans and most lower-income families had lower payment to debt ratios relative to their counterparts in 2004 than in 1989, for instance. This seems to mask, though, a widening of the difference in debt payments by race and by income between 2001 and 2004 (Table 9).

Hispanics, who seem to have experienced some improvements in credit constraints, though, seem to have also experienced a deterioration in their costs of credit. Specifically, the difference in debt payments relative to debt grew relative to Whites from 1989 and 2001 to 2004 (Table 9).

*** INSERT TABLE 9 ABOUT HERE *** 
The differences in debt payments may reflect differences in interest rates. To see if this is the case, I perform F-tests on interest rates for select loan types - mortgages, installment loans, and credit cards. ${ }^{9}$ As with the previous tests, a "+" in individual years indicates that interest rates are higher for minorities and lower-income families than for their counterparts. When years are compared, a "+" suggests that the difference of interest rates charged to different groups has declined and a "_" indicates that the difference has increased over time.

The results indicate that, with few exceptions, interest rates charged to minorities and lower-income families were greater than those charged to Whites and families in the top income quintile (see Table 10). ${ }^{10}$

\section{*** INSERT TABLE 10 ABOUT HERE***}

Unlike the difference in debt payments, the gap in interest rates tended to widen from 1989 to 2004 by income and by race. For instance, the difference of mortgage rates charged to African-Americans relative to that charged to Whites was greater in 2004 than in 1989. This masks a shrinking mortgage interest rate differential from 2001 to 2004 by race, though. Also, for all income quintiles, the differences in mortgage rates relative to the top quintile widened by 2004, relative to 1989 and 2001. Also, differences in interest rates on installment credit by race and for the bottom $60 \%$ of the income distribution relative to the top quintile either stayed the same or increased by 2004 as compared to 1989 (Table 10). And differences in credit card interest rates by race and for low-income families relative to their counterparts did not change from 2001 to 2004.

In comparison, interest rate differentials improved by ethnicity, though. For instance, the difference in mortgage interest rates between Hispanic families and white families shrank between 1989 and 2004, although it increased between 2001 and 2004 (see Table 10). At the same time, the difference between Hispanics and whites in installment credit interest rates declined between 2001 and 2004, but that only meant that the gap in 2004 was as large as in 1989.

These trends go against the observed trends in debt payments. That is, for groups, for whom the differentials in debt payments shrunk, interest differentials widened and vice versa. In the former case, groups, especially African-Americans and lower-income families may have been able to change the composition of their debt or their other payment terms to lower their debt payments. In comparison, for Hispanics, who saw narrowing interest rate differentials, but widening payment differentials with Whites, differences in other cost components, such as fees, may have increased.

\section{IV.3 Differences in loan sources and loan types between groups and over time}

Finally, minorities may rely more heavily on more costly sources and types of loans. To see if this is the case and if this has changed over time, two separate tests are performed. I

\footnotetext{
${ }^{9}$ The interest rates reported here are only for the most recent loan in each category.

${ }^{10}$ Data on credit card interest rates do not exist for 1989.
} 
first test if the differences of the probability of having a loan from a particular source or in a particular form have changed over time by demographic characteristics. Next, I test if among families with debt, the relative importance of particular sources or types of loans differs and if those differences have changed over time. Here I consider traditional banks - commercial banks, mortgage banks, and savings and loans - credit unions, and consumer banks - finance companies and credit card companies - as loan sources. In addition, I consider mortgages, installment loans, and credit card debt as types of loans.

First, I perform a CMH test to see if the odds ratios of having loans from specific sources or of specific types have changed over time. The hypothesis is that the minority and lower-income families should become more like their counterparts in borrowing from specific sources. This is denoted by a "+" in Table 11, while a "-“ indicates that the probabilities have moved apart.

There has been some equalization with respect to traditional banks. For instance, the odds ratio between African-Americans and Whites for borrowing from a traditional bank has shrunk from 1989 to 2004, although the gap widened again from 2001 to 2004. In comparison, families in the bottom quintile relative to those in the top quintile caught up in the probability of having loans from traditional lenders between 2001 and 2004, which left the differential in 2004 the same as in 1989 (Table 11). Yet, there was no change in the differential by ethnicity in 2004 relative to 2001 or 1989.

\section{*** INSERT TABLE 11 ABOUT HERE ***}

Also, most groups have become increasingly similar with respect to loans from credit unions. Hispanics and lower-income families have seen shrinking differences in the likelihood of holding a loan from credit unions relative to their counterparts by 2004 as compared to 2001 or 1989 (Table 11). In contrast, though, the difference in the probability of a credit union loan by race has widened, so that African-Americans became relatively less likely than Whites to have a loan from credit unions.

What about loan types? Here the data show more divergence among the groups. AfricanAmericans and families in the bottom and third quintile shrank the gaps to their counterparts with respect to mortgages between 1989 and 2004. For others, especially Hispanics and families in the second and fourth quintile, though, the gap in mortgage probabilities widened between 1989 and 2004. At the same time, the gap with respect to installment loans widened by ethnicity and by income, except for families in the fourth quintile (Table 11).

In general, access to potentially lower-cost borrowers increased for minorities and lowerincome families by 2004 compared to earlier years, whereas there is no clear trend towards equalization for the use of typically lower cost forms of credit. Particularly Hispanics and moderate-income families became disproportionately more likely to have loans from more costly types, while African-Americans seem to have become a little more equal to Whites with respect to holding specific types of loans. 
Next, I test if the relative shares of loans from particular sources and types of loans have become more equal over time for families, who have any debt. To see if differences exist between groups and if these differences have changed over time, I use an F-test. For individual years, a "_-" signals that the share of loans from a specific source or in a specific form for minorities and lower-income families was smaller than for their counterparts, while a "+" indicates that it was larger. For comparison between years, a "+” again indicates an improvement, reflected in smaller differences, whereas a “-“ signals a deterioration due to a widening differential.

The results for loan sources show that minorities and lower-income families received smaller shares of their total debt from traditional lenders than their counterparts did (Table 12). In contrast, minorities and lower-income families got a larger share of their loans from consumer banks than their counterparts did. Minorities and lower-income families hence received more credit from more expensive sources.

Importantly, the results show that the differences in the relative importance of traditional banks for the supply of credit by race, ethnicity, and income did not change between 1989 and 2004. Only families in the second quintile of the income distribution saw their difference relative to families in the top income shrink, which masks, however, a widening difference between 2001 and 2004 (Table 12).

Moreover, the gap with respect to loans from consumer banks shrunk for most groups. Specifically, between 1989 and 2004, the difference in the loan shares from consumer banks declined between Hispanics and lower-income families and their counterparts (Table 12). In comparison, the difference by race remained steady.

By 2004, minorities and lower-income families still borrowed more heavily than their counterparts from sources that are typically more expensive. The gap shrunk over time, largely because the relative differences in borrowing from more expensive sources, such as finance companies and credit card companies narrowed, not because the differences in borrowing from less expensive ones, such as commercial banks, mortgage banks, and savings and loans, decreased.

Lastly, the trends for the types of loans confirm that minorities and lower-income families borrowed more from more costly sources and that these differences changed little over time. Specifically, minorities and lower-income families borrowed more heavily in the form of installment loans and credit card debt and relied less on mortgages than their counterparts. Moreover, with a few exceptions, the differences in the use of mortgages and installment loans stayed the same or widened between 1989 and 2004. In comparison, the differences in the shares of debt coming from credit card balances shrunk by income and by ethnicity, but widened by race from 1989 to 2004. Overall, though, there is no clear indication that during financial market deregulation borrowers with different demographic characteristics became more alike. By 2004, lower-income families and minorities depended on more costly forms of credit more so than their counterparts to the same degree as they did in 1989. 


\section{Conclusion}

Over the past few decades, financial markets became increasingly deregulated and household debt grew, at times rapidly. One expectation was that greater deregulation may benefit borrowers. In particular, credit access should have increased and differences in credit access by demographic characteristics should have declined.

The figures presented here show no universal trend towards equalization in terms of credit access across groups. In most instances, there is an indication that gaps in credit access, measured by loan denials, discouraged applications, and costs of credit, stayed the same or widened from 1989 to 2004.

Minorities and lower-income families face larger credit constraints than their counterparts and this has only changed for some groups. In particular, lower-income families faced a widening gap in credit constraints relative to higher-income families since 1989. The credit constraint gap between African-Americans and Whites narrowed in terms of discouraged applications, but widened with respect to loan denials. And, credit constraints eased for Hispanics, as both the gap in loan denials and discouraged applications with Whites decreased since 1989.

With respect to debt payments and interest rates, the results show some diverging trends. For groups, for whom the debt payment differential shrunk, interest differentials widened and vice versa. In the former case, groups, especially African-Americans and lowerincome families, possibly could change the composition of their debt or their other payment terms to lower their debt payments. In comparison, for Hispanics, who saw narrowing interest rate differentials, but widening payment differentials with Whites, differences in other cost components, such as fees, potentially increased.

Finally, financial deregulation was expected to lower differences in the sources of loans and the loan types by demographic characteristics. This was the case only to a limited degree. By 2004, minorities and lower-income families still borrowed more heavily than their counterparts from sources that are typically more expensive. The gap shrunk over time, because the relative differences in borrowing from more expensive sources narrowed. Also, minorities and lower-income families borrowed more from more costly types, but by 2004, lower-income families and minorities depended on more costly forms of credit more so than their counterparts to the same degree as they did in 1989. 
Table 1: Share of families with debt, 1989 to 2004

\begin{tabular}{|c|c|c|c|c|c|c|c|c|c|}
\hline Year & 1989 & 1992 & 1995 & 1998 & 2001 & 2004 & 1989 to 2001 & 2001 to 2004 & 1989 to 2004 \\
\hline Total & 72.2 & 73.3 & 74.5 & 74.0 & 75.1 & 76.4 & 2.9 & 1.3 & 4.2 \\
\hline White & 73.2 & 74.3 & 75.4 & 74.9 & 75.8 & 77.9 & 2.7 & 2.1 & 4.8 \\
\hline Black & 65.1 & 69.2 & 71.1 & 68.6 & 74.0 & 74.5 & 8.9 & 0.5 & 9.4 \\
\hline Hispanic & 72.4 & 69.3 & 75.4 & 72.3 & 71.3 & 70.3 & -1.1 & -1.0 & -2.2 \\
\hline Bottom quintile & 48.9 & 51.7 & 80.4 & 50.2 & 50.3 & 52.8 & 1.4 & 2.6 & 4.0 \\
\hline Middle quintile & 79.5 & 79.7 & 83.0 & 81.0 & 83.0 & 84.2 & 3.5 & 1.2 & 4.7 \\
\hline Fourth quintile & 86.8 & 85.0 & 88.7 & 89.1 & 86.5 & 86.3 & -0.4 & -0.2 & -0.5 \\
\hline Top quintile & 90.2 & 87.8 & 88.0 & 88.9 & 88.2 & 89.2 & -2.0 & 1.0 & -1.0 \\
\hline
\end{tabular}

Notes: All figures are in percent. Changes are in percentage points. Author's calculations based on BOG (2006). Income limits for quintiles are taken from Census (2005). 
Table 2: Share of families, who were credit constrained, 1989 to 2004

\begin{tabular}{|c|c|c|c|c|c|c|c|c|c|}
\hline Year & 1989 & 1992 & 1995 & 1998 & 2001 & 2004 & 1989 to 2001 & 2001 to 2004 & 1989 to 2004 \\
\hline \multicolumn{10}{|c|}{ Applied, denied, and could not get full amount elsewhere } \\
\hline Total & 11.6 & 14.8 & 12.1 & 12.6 & 12.3 & 13.0 & 0.7 & 0.7 & 1.4 \\
\hline White & 10.1 & 12.4 & 10.3 & 11.5 & 10.8 & 10.8 & 0.8 & 0.0 & 0.7 \\
\hline Black & 13.0 & 25.4 & 20.2 & 20.0 & 18.3 & 22.0 & 5.3 & 3.7 & 9.0 \\
\hline Hispanic & 20.6 & 21.6 & 17.0 & 13.9 & 16.1 & 18.1 & -4.5 & 2.0 & -2.5 \\
\hline Bottom quintile & 11.9 & 17.2 & 13.0 & 12.7 & 12.2 & 13.2 & 0.3 & 1.0 & 1.3 \\
\hline Second quintile & 17.1 & 17.8 & 15.1 & 15.4 & 17.0 & 19.4 & -0.1 & 2.4 & 2.3 \\
\hline Middle quintile & 11.3 & 16.8 & 13.0 & 16.7 & 15.0 & 15.7 & 3.6 & 0.7 & 4.4 \\
\hline Fourth quintile & 12.2 & 12.6 & 12.0 & 10.4 & 11.0 & 12.7 & -1.2 & 1.7 & 0.5 \\
\hline Top quintile & 4.8 & 8.1 & 6.1 & 7.0 & 5.8 & 4.5 & 1.0 & -1.3 & -0.3 \\
\hline \multicolumn{10}{|c|}{ Did not apply because of fear of being turned down } \\
\hline Total & 5.5 & 5.3 & 8.3 & 6.7 & 7.0 & 6.9 & 1.5 & -0.1 & 1.4 \\
\hline White & 3.4 & 3.7 & 5.7 & 4.4 & 4.1 & 4.9 & 0.7 & 0.7 & 1.5 \\
\hline Black & 13.5 & 8.6 & 21.3 & 15.2 & 16.6 & 14.9 & 3.2 & -1.8 & 1.4 \\
\hline Hispanic & 10.5 & 14.6 & 13.8 & 17.3 & 16.5 & 11.9 & 6.0 & -4.6 & 1.4 \\
\hline Bottom quintile & 10.8 & 8.8 & 15.2 & 12.5 & 13.6 & 11.9 & 2.8 & -1.7 & 1.2 \\
\hline Second quintile & 5.9 & 5.9 & 8.7 & 8.3 & 9.7 & 10.2 & 3.9 & 0.5 & 4.4 \\
\hline Middle quintile & 3.6 & 4.9 & 8.3 & 4.6 & 5.8 & 6.6 & 2.2 & 0.8 & 3.0 \\
\hline Fourth quintile & 2.7 & 3.4 & 3.4 & 3.4 & 3.3 & 2.6 & 0.7 & -0.7 & 0.0 \\
\hline Top quintile & 2.8 & 2.0 & 2.3 & 2.1 & 1.5 & 2.9 & -1.3 & 1.3 & 0.1 \\
\hline \multicolumn{10}{|c|}{ Shares of household who are credit constrained } \\
\hline Total & 17.1 & 20.0 & 20.4 & 19.3 & 19.3 & 19.9 & 2.2 & 0.6 & 2.8 \\
\hline White & 13.5 & 16.1 & 15.9 & 15.9 & 15.0 & 15.6 & 1.5 & 0.7 & 2.2 \\
\hline Black & 26.5 & 34.1 & 41.5 & 35.2 & 34.9 & 36.9 & 8.4 & 2.0 & 10.4 \\
\hline Hispanic & 31.1 & 36.2 & 30.8 & 31.2 & 32.6 & 30.0 & 1.5 & -2.6 & -1.1 \\
\hline Bottom quintile & 22.7 & 26.0 & 28.3 & 25.2 & 25.8 & 25.1 & 3.2 & -0.7 & 2.4 \\
\hline Second quintile & 22.9 & 23.8 & 23.9 & 23.7 & 26.7 & 29.6 & 3.8 & 2.9 & 6.7 \\
\hline Middle quintile & 14.9 & 21.7 & 21.3 & 21.3 & 20.8 & 22.3 & 5.9 & 1.5 & 7.4 \\
\hline Fourth quintile & 14.8 & 16.0 & 15.4 & 13.8 & 14.3 & 15.3 & -0.5 & 1.0 & 0.5 \\
\hline Top quintile & 7.6 & 10.1 & 8.4 & 9.1 & 7.3 & 7.4 & -0.3 & 0.0 & -0.2 \\
\hline
\end{tabular}


Table 3: Trends in debt payments relative to debt, 1989 to 2004

\begin{tabular}{|c|c|c|c|c|c|c|c|c|c|}
\hline Year & 1989 & 1992 & 1995 & 1998 & 2001 & 2004 & 1989 to 2001 & 2001 to 2004 & 1989 to 2004 \\
\hline Total & 28.2 & 24.9 & 23.7 & 21.6 & 20.8 & 16.8 & -7.4 & -4.0 & -11.4 \\
\hline White & 25.5 & 23.0 & 22.0 & 20.4 & 19.6 & 15.7 & -5.9 & -3.8 & -9.7 \\
\hline Black & 36.0 & 30.0 & 30.0 & 29.4 & 28.6 & 22.1 & -7.5 & -6.4 & -13.9 \\
\hline Hispanic & 29.9 & 30.0 & 25.0 & 29.7 & 25.9 & 19.7 & -4.0 & -6.2 & -10.2 \\
\hline Bottom quintile & 36.6 & 30.0 & 30.0 & 30.0 & 30.0 & 27.7 & -6.6 & -2.3 & -8.9 \\
\hline Second quintile & 30.0 & 30.0 & 30.0 & 30.0 & 30.0 & 23.2 & 0.0 & -6.8 & -6.8 \\
\hline Middle quintile & 30.0 & 27.3 & 25.7 & 24.0 & 24.6 & 17.4 & -5.4 & -7.1 & -12.6 \\
\hline Fourth quintile & 23.1 & 22.0 & 20.0 & 17.8 & 18.7 & 16.0 & -4.5 & -2.7 & -7.2 \\
\hline Top quintile & 20.3 & 17.6 & 17.1 & 16.7 & 15.9 & 13.3 & -4.3 & -2.6 & -7.0 \\
\hline
\end{tabular}

Notes: All figures are in percent. Author’s calculations based on BOG (2006). Income limits for quintiles are taken from Census (2005). 
Table 4: Summary statistics on select interest rates, 2004

\begin{tabular}{|c|c|c|c|c|c|c|}
\hline & Credit cards & Mortgages & Car loans & Education loans & Line of credit & Installment loans \\
\hline \multicolumn{7}{|c|}{ Average interest rates on specified loans } \\
\hline Total & 12.7 & 6.3 & 7.7 & 4.9 & 5.7 & 12.3 \\
\hline White & 12.6 & 6.2 & 7.2 & 4.7 & 5.7 & 12.1 \\
\hline Black & 13.2 & 7.4 & 10.0 & 5.7 & 6.4 & 12.6 \\
\hline Hispanic & 13.6 & 6.7 & 9.2 & 4.6 & 5.8 & 12.7 \\
\hline Bottom quintile & 13.3 & 7.2 & 9.0 & 5.2 & 5.6 & 14.2 \\
\hline Second quintile & 13.4 & 7.0 & 8.9 & 5.3 & 6.6 & 14.0 \\
\hline Middle quintile & 13.0 & 6.6 & 8.8 & 4.8 & 6.4 & 11.3 \\
\hline Fourth quintile & 12.4 & 6.2 & 7.3 & 4.6 & 5.8 & 11.1 \\
\hline Top quintile & 12.0 & 5.7 & 5.9 & 4.8 & 5.1 & 9.7 \\
\hline \multicolumn{7}{|c|}{ Shares of families with interest rates 8 pct. pt. above prime rate in 2004} \\
\hline Total & 46.7 & 1.6 & 11.2 & 1.6 & 3.9 & 40.4 \\
\hline White & 46.0 & 0.9 & 8.9 & 0.9 & 3.8 & 37.1 \\
\hline Black & 47.3 & 7.7 & 23.3 & 5.4 & 7.8 & 48.7 \\
\hline Hispanic & 53.1 & 2.2 & 18.5 & 0.7 & 0.0 & 51.3 \\
\hline Bottom quintile & 52.5 & 4.2 & 13.6 & 3.8 & 2.1 & 52.4 \\
\hline Second quintile & 50.9 & 4.0 & 16.5 & 4.3 & 8.2 & 51.6 \\
\hline Middle quintile & 48.2 & 1.7 & 16.5 & 1.3 & 8.4 & 37.1 \\
\hline Fourth quintile & 43.8 & 1.7 & 10.0 & 0.5 & 2.9 & 28.9 \\
\hline Top quintile & 43.2 & 0.2 & 3.3 & 0.0 & 2.0 & 25.1 \\
\hline
\end{tabular}

Notes: All figures are in percent. Author’s calculations based on BOG (2006). Income limits for quintiles are taken from Census (2005). 
Table 5: Aggregate shares of specific debt type, 2004

\begin{tabular}{|c|c|c|c|c|c|c|}
\hline & Mortgages & $\begin{array}{c}\text { Other } \\
\text { residential } \\
\text { real estate } \\
\text { debt }\end{array}$ & $\begin{array}{c}\text { Other } \\
\text { lines of } \\
\text { credit }\end{array}$ & $\begin{array}{c}\text { Credit } \\
\text { card } \\
\text { balances }\end{array}$ & $\begin{array}{c}\text { Installment } \\
\text { credit }\end{array}$ & $\begin{array}{c}\text { Other } \\
\text { debt }\end{array}$ \\
\hline Total & 75.3 & 8.6 & 0.7 & 3.0 & 10.8 & 1.6 \\
\hline White & 75.8 & 8.2 & 0.8 & 2.9 & 10.5 & 1.8 \\
\hline Black & 70.5 & 6.2 & 0.0 & 3.7 & 18.2 & 1.4 \\
\hline Hispanic & 76.8 & 7.9 & 0.5 & 3.3 & 10.9 & 0.6 \\
\hline Bottom quintile & 60.4 & 5.6 & 1.2 & 5.9 & 25.0 & 2.8 \\
\hline Second quintile & 70.6 & 3.6 & 0.6 & 5.3 & 18.7 & 1.5 \\
\hline Middle quintile & 76.8 & 3.9 & 0.5 & 4.7 & 13.5 & 0.9 \\
\hline Fourth quintile & 79.6 & 3.9 & 0.8 & 3.3 & 12.4 & 0.5 \\
\hline Top quintile & 74.6 & 13.1 & 0.4 & 1.7 & 7.2 & 2.2 \\
\hline
\end{tabular}

Notes: Shares are the ratio of aggregate debt of a specific type for a particular group relative to the total debt for that group. All figures are in percent. Author's calculations based on BOG (2006). Income limits for quintiles are taken from Census (2005). 
Table 6: Aggregate shares of specific debt sources, 2004

\begin{tabular}{|c|c|c|c|c|c|c|c|c|c|}
\hline & $\begin{array}{c}\text { Credit } \\
\text { unions }\end{array}$ & & & & $\begin{array}{c}\text { Total, } \\
\text { traditional } \\
\text { lenders }\end{array}$ & & & $\begin{array}{c}\text { Total, } \\
\text { consumer } \\
\text { banks }\end{array}$ & Other \\
\hline & & $\begin{array}{c}\text { Com. } \\
\text { banks }\end{array}$ & $\begin{array}{c}\text { Savings \& } \\
\text { Loans }\end{array}$ & $\begin{array}{c}\text { Real estate } \\
\text { lenders }\end{array}$ & & $\begin{array}{c}\text { Finance } \\
\text { cos. }\end{array}$ & $\begin{array}{c}\text { Credit } \\
\text { card } \\
\text { lender }\end{array}$ & & \\
\hline Total & $3.6 \%$ & $34.8 \%$ & $7.3 \%$ & $35.5 \%$ & $77.6 \%$ & $8.0 \%$ & $3.3 \%$ & $11.2 \%$ & $7.5 \%$ \\
\hline White & $4.0 \%$ & $36.0 \%$ & $7.6 \%$ & $34.0 \%$ & $77.7 \%$ & $7.3 \%$ & $3.2 \%$ & $10.5 \%$ & $7.9 \%$ \\
\hline Black & $3.9 \%$ & $31.3 \%$ & $7.1 \%$ & $34.0 \%$ & $72.3 \%$ & $8.3 \%$ & $4.2 \%$ & $12.4 \%$ & $11.3 \%$ \\
\hline Hispanic & $1.6 \%$ & $28.6 \%$ & $6.4 \%$ & $46.0 \%$ & $81.0 \%$ & $11.0 \%$ & $3.7 \%$ & $14.7 \%$ & $2.8 \%$ \\
\hline Bottom quintile & $2.7 \%$ & $35.6 \%$ & $6.9 \%$ & $24.3 \%$ & $66.8 \%$ & $7.4 \%$ & $5.9 \%$ & $13.2 \%$ & $17.4 \%$ \\
\hline Second quintile & $4.0 \%$ & $27.8 \%$ & $4.5 \%$ & $35.5 \%$ & $67.8 \%$ & $8.5 \%$ & $5.4 \%$ & $13.9 \%$ & $14.4 \%$ \\
\hline Middle quintile & $3.8 \%$ & $30.9 \%$ & $5.8 \%$ & $37.4 \%$ & $74.0 \%$ & $10.4 \%$ & $4.9 \%$ & $15.3 \%$ & $6.9 \%$ \\
\hline Fourth quintile & $4.4 \%$ & $34.6 \%$ & $7.5 \%$ & $36.6 \%$ & $78.7 \%$ & $9.0 \%$ & $3.6 \%$ & $12.6 \%$ & $4.3 \%$ \\
\hline Top quintile & $3.3 \%$ & $37.0 \%$ & $8.1 \%$ & $35.3 \%$ & $80.4 \%$ & $6.7 \%$ & $2.2 \%$ & $8.9 \%$ & $7.4 \%$ \\
\hline
\end{tabular}

Notes: Shares are the ratio of aggregate debt of a specific source for a particular group relative to the total debt for that group. Traditional lenders comprise commercial banks, savings and loans, and real estate lenders. Consumer banks comprise finance companies and credit card lenders. All figures are in percent. Author's calculations based on BOG (2006). Income limits for quintiles are taken from Census (2005). 
Table 7: Tests of differences between groups and over time of loan denial rates and discouraged application rates

\begin{tabular}{|c|c|c|c|c|c|c|c|c|c|}
\hline \multirow{3}{*}{$\begin{array}{l}\text { Ratios to be tested } \\
\text { African-Americans/white }\end{array}$} & \multirow{3}{*}{$\begin{array}{l}\text { Test } \\
\mathrm{CMH}\end{array}$} & \multicolumn{4}{|c|}{ Loan denials } & \multicolumn{4}{|c|}{ Discouraged applications } \\
\hline & & \multicolumn{2}{|c|}{2004 to 1989} & \multicolumn{2}{|c|}{2004 to 2001} & \multicolumn{2}{|c|}{2004 to 1989} & \multicolumn{2}{|c|}{2004 to 2001} \\
\hline & & "-" & $\begin{array}{c}4.01^{* *} \\
\left(216.36^{* * *}\right)\end{array}$ & "-" & $\begin{array}{c}2.30 \\
\left(47.77^{* * *}\right)\end{array}$ & $"+"$ & $\begin{array}{c}0.67 \\
\left(32.61^{* * *}\right)\end{array}$ & "+" & $\begin{array}{c}1.64 \\
(56.80 * * *)\end{array}$ \\
\hline & $\mathrm{BD}$ & "-" & $\begin{array}{c}4.03^{* *} \\
(217.54 * * *)\end{array}$ & "-" & $\begin{array}{c}2.30 \\
\left(47.81^{* * *}\right)\end{array}$ & $"+"$ & $\begin{array}{c}0.67 \\
(32.65 * * *)\end{array}$ & $"+"$ & $\begin{array}{c}1.65 \\
(56.88 * * *)\end{array}$ \\
\hline & $\mathrm{MH}$ & $"+"$ & $\begin{array}{c}115.36 * * * \\
(1274.72 * * *)\end{array}$ & "+" & $\begin{array}{c}151.06 * * * \\
\left(2028.83^{* * *}\right)\end{array}$ & $"+"$ & $\begin{array}{c}209.03 * * * \\
(4241.30 * * *)\end{array}$ & $"+"$ & $\begin{array}{c}295.15^{* * *} \\
(5301.08 * * *)\end{array}$ \\
\hline \multirow[t]{3}{*}{ Hispanics/white } & $\mathrm{CMH}$ & "+" & $\begin{array}{c}0.16 \\
\left(32.73^{* * *}\right)\end{array}$ & "-" & $\begin{array}{c}1.13 \\
\left(12.82^{* * *}\right)\end{array}$ & $"+"$ & $\begin{array}{c}3.71^{*} \\
(20.37 * * *)\end{array}$ & "+" & $\begin{array}{c}4.55^{* *} \\
\left(134.96^{* * *}\right)\end{array}$ \\
\hline & $\mathrm{BD}$ & $"+"$ & $\begin{array}{c}0.16 \\
\left(32.76^{* * *}\right)\end{array}$ & "-" & $\begin{array}{c}1.14 \\
\left(12.82^{* * *}\right)\end{array}$ & "+" & $\begin{array}{c}3.76 * * \\
(20.39 * * *)\end{array}$ & "+" & $\begin{array}{c}4.57 * * \\
(135.65 * * *)\end{array}$ \\
\hline & MH & "+" & $\begin{array}{c}64.02^{* * *} \\
(1153.26 * * *)\end{array}$ & "+" & $\begin{array}{c}54.72 * * * \\
(646.40 * * *)\end{array}$ & "+" & $\begin{array}{c}77.04 * * * \\
\left(1647.48^{* * *}\right)\end{array}$ & "+" & $\begin{array}{c}117.52 * * * \\
(2877.94 * * *)\end{array}$ \\
\hline \multirow[t]{3}{*}{ bottom quintile/top quintile } & $\mathrm{CMH}$ & "-" & $\begin{array}{c}2.01 \\
\left(12.12^{* * *}\right)\end{array}$ & "-" & $\begin{array}{c}1.45 \\
\left(49.43^{* * *}\right)\end{array}$ & "-" & $\begin{array}{c}1.26 \\
(1.39)\end{array}$ & "+" & $\begin{array}{c}3.02^{*} \\
\left(119.22^{* * *}\right)\end{array}$ \\
\hline & $\mathrm{BD}$ & "-" & $\begin{array}{c}2.01 \\
\left(12.12^{* * *}\right)\end{array}$ & "-" & $\begin{array}{c}1.45 \\
\left(49.55^{* * *}\right)\end{array}$ & "-" & $\begin{array}{c}1.27 \\
(1.39)\end{array}$ & "+" & $\begin{array}{c}3.05^{*} \\
(120.85 * * *)\end{array}$ \\
\hline & $\mathrm{MH}$ & "+" & $\begin{array}{c}164.69 * * * \\
\left(1657.81^{* * *}\right)\end{array}$ & "+" & $\begin{array}{c}197.30 * * * \\
\left(1535.47^{* * *}\right)\end{array}$ & "+" & $\begin{array}{c}224.82 * * * \\
(2242.23 * * *)\end{array}$ & "+" & $\begin{array}{c}351.98 * * * \\
(3417.55 * * *)\end{array}$ \\
\hline \multirow[t]{3}{*}{ second quintile/top quintile } & $\mathrm{CMH}$ & "-" & $\begin{array}{c}7.06^{* * *} \\
\left(18.46^{* * *}\right)\end{array}$ & "-" & $\begin{array}{c}2.08 \\
(79.52 * * *)\end{array}$ & "-" & $\begin{array}{c}3.82 * * \\
(63.71 * * *)\end{array}$ & "+" & $\begin{array}{c}2.65^{*} \\
(62.74 * * *)\end{array}$ \\
\hline & $\mathrm{BD}$ & "-" & $\begin{array}{c}7.13^{* * *} \\
\left(18.48^{* * *}\right)\end{array}$ & "-" & $\begin{array}{c}2.08 \\
\left(79.80^{* * *}\right)\end{array}$ & "-" & $\begin{array}{c}3.88 * * \\
(64.17 * * *)\end{array}$ & "+" & $\begin{array}{c}2.67^{*} \\
\left(63.23^{* * *}\right)\end{array}$ \\
\hline & MH & $"+"$ & $\begin{array}{c}271.35^{* * *} \\
(3751.96 * * *)\end{array}$ & "+" & $\begin{array}{c}369.91 * * * \\
(3567.02 * * *)\end{array}$ & "+" & $\begin{array}{c}141.35^{* * *} \\
\left(1132.45^{* * *}\right)\end{array}$ & "+" & $\begin{array}{c}264.24 * * * \\
\left(2242.40^{* * *}\right)\end{array}$ \\
\hline
\end{tabular}




\begin{tabular}{|c|c|c|c|c|c|c|c|c|c|}
\hline \multirow{2}{*}{$\begin{array}{l}\text { Ratios to be tested } \\
\text { middle quintile/top quintile }\end{array}$} & \multirow{2}{*}{$\begin{array}{l}\text { Test } \\
\mathrm{CMH}\end{array}$} & \multicolumn{5}{|c|}{ Loan denials } & \multicolumn{3}{|c|}{ Discouraged applications } \\
\hline & & "-" & $\begin{array}{c}3.76^{* *} \\
\left(63.35^{* * *}\right)\end{array}$ & "-" & $\begin{array}{c}0.85 \\
\left(45.70^{* * *}\right)\end{array}$ & "-" & $\begin{array}{c}4.07 * * \\
\left(59.17^{* * *}\right)\end{array}$ & "+" & $\begin{array}{c}0.84 \\
(40.89 * * *)\end{array}$ \\
\hline & $\mathrm{BD}$ & "-" & $\begin{array}{c}3.78 * * \\
(63.61 * * *)\end{array}$ & "-" & $\begin{array}{c}0.85 \\
(45.80 * * *)\end{array}$ & "-" & $\begin{array}{c}4.16 * * \\
(59.69 * * *)\end{array}$ & $"+"$ & $\begin{array}{c}0.85 \\
\left(41.14^{* * *}\right)\end{array}$ \\
\hline & $\mathrm{MH}$ & "+" & $\begin{array}{c}181.12^{* * *} \\
\left(2029.55^{* * *}\right)\end{array}$ & "+" & $\begin{array}{c}250.47 * * * \\
(2424.59 * * *)\end{array}$ & "+" & $\begin{array}{c}59.37 * * * \\
(309.62 * * *)\end{array}$ & $"+"$ & $\begin{array}{c}129.97 * * * \\
\left(831.81^{* * *}\right)\end{array}$ \\
\hline \multirow[t]{3}{*}{ fourth quintile/top quintile } & $\mathrm{CMH}$ & "-" & $1.63(5.07 * *)$ & "-" & $\begin{array}{c}1.69 \\
\left(71.09^{* * *}\right)\end{array}$ & "-" & $0.01(0.33)$ & $"+"$ & $\begin{array}{c}1.14 \\
\left(93.25^{* * *}\right)\end{array}$ \\
\hline & $\mathrm{BD}$ & "-" & $1.64(5.07 * *)$ & "-" & $\begin{array}{c}1.70 \\
(71.34 * * *)\end{array}$ & "-" & $0.01(0.33)$ & $"+"$ & $\begin{array}{c}1.15 \\
\left(94.74^{* * *}\right)\end{array}$ \\
\hline & $\mathrm{MH}$ & $"+"$ & $\begin{array}{c}151.83^{* * *} \\
\left(1552.17^{* * *}\right)\end{array}$ & $"+"$ & $\begin{array}{c}129.97 * * * \\
(1245.52 * * *)\end{array}$ & $"+"$ & $\begin{array}{c}11.37^{* * *} \\
(2.02)\end{array}$ & $"+"$ & $\begin{array}{c}19.99 * * * \\
(45.03 * * *)\end{array}$ \\
\hline
\end{tabular}

Notes: CMH stands for Cochran-Mantel-Haenszel test, BD for Breslow-Day test, and MH for Mantel-Haenszel test. Figures are for unweighted data. *** indicates significance at $1 \%$-level, $* *$ indicates significance at $5 \%$-level, and $*$ indicates significance at $10 \%$-level. Figures in parentheses are for approximated weighted tests. To allow for test calculations, weights have been divided by 1,000 and rounded. Results do not change materially if weights are divided by 10 or 100. Using full weights exceeds computational limits of software program. "+" indicates that the odds ratio in 2004 was closer to one than in the comparison year, 1989 or 2001, and "-" indicates it further away from one. Income limits for quintiles are taken from Census (2005). 
Table 8: Tests for odds ratios over time, by income

\begin{tabular}{|c|c|c|c|c|c|}
\hline & & \multicolumn{2}{|c|}{ Loan Denials } & \multicolumn{2}{|c|}{ Discouraged applications } \\
\hline & & $\begin{array}{c}2004 \text { to } \\
1989\end{array}$ & $\begin{array}{c}2004 \text { to } \\
2001\end{array}$ & $\begin{array}{c}2004 \text { to } \\
1989\end{array}$ & $\begin{array}{c}2004 \text { to } \\
2001\end{array}$ \\
\hline \multirow{6}{*}{$\begin{array}{l}\text { African- } \\
\text { Americans/whites }\end{array}$} & Difference in OR & "+ & "+ & "+ & "+ \\
\hline & Bottom quintile & $\begin{array}{c}0.78 \\
\left(7.41^{* * *}\right)\end{array}$ & $\begin{array}{c}7.16^{* * *} \\
(226.24 * * *)\end{array}$ & $\begin{array}{c}11.07 * * * \\
(337.40 * * *)\end{array}$ & $\begin{array}{c}18.34 * * * \\
(632.80 * * *)\end{array}$ \\
\hline & Second quintile & $\begin{array}{c}12.39 * * * \\
(241.77 * * *)\end{array}$ & $\begin{array}{c}19.43^{* * *} \\
\left(560.61^{* * *}\right)\end{array}$ & $\begin{array}{c}31.45^{* * *} \\
(1031.58 * * *\end{array}$ & $\begin{array}{c}32.23 * * * \\
(1065.98 * * *\end{array}$ \\
\hline & Middle quintile & $\begin{array}{c}13.13^{* * *} \\
(327.46 * * *)\end{array}$ & $\begin{array}{c}4.70 * * * \\
(106.37 * * *)\end{array}$ & $\begin{array}{c})^{21.35^{* * *}} \\
(689.06)\end{array}$ & $\begin{array}{c}\text { ) } \\
40.26 * * * \\
\left(1211.45^{* * *}\right.\end{array}$ \\
\hline & Fourth quintile & $\begin{array}{c}11.76^{* * *} \\
\left(258.92^{* * *}\right)\end{array}$ & $\begin{array}{c}18.18 * * * \\
(480.51 * * *)\end{array}$ & $\begin{array}{c}14.81 * * * \\
(463.58 * * *)\end{array}$ & $\begin{array}{c}) \\
15.58 * * * \\
(374.12 * * *)\end{array}$ \\
\hline & Top quintile & $\begin{array}{c}32.89 * * * \\
(792.30 * * *)\end{array}$ & $\begin{array}{c}31.70 * * * \\
(713.86 * * *)\end{array}$ & $\begin{array}{c}9.12 * * \\
(188.08 * * *)\end{array}$ & $\begin{array}{c}29.08 * * * \\
\left(354.87^{* * *}\right)\end{array}$ \\
\hline \multirow[t]{6}{*}{ Hispanics/white } & Difference in OR & "+ & "+" & "+ & $"+"$ \\
\hline & Bottom quintile & $0.00(0.00)$ & $\begin{array}{c}1.42 \\
\left(11.41^{* * *}\right)\end{array}$ & $\begin{array}{c}2.18 \\
\left(13.25^{* * *}\right)\end{array}$ & $\begin{array}{c}7.84 * * * \\
(36.26 * * *)\end{array}$ \\
\hline & Second quintile & $\begin{array}{c}10.51^{* * *} \\
\left(50.24^{* * *}\right)\end{array}$ & $\begin{array}{c}2.62 \\
(7.97 * *)\end{array}$ & $\begin{array}{c}5.54^{* *} \\
\left(20.95^{* * *}\right)\end{array}$ & $\begin{array}{c}8.50 * * * \\
(40.42 * * *)\end{array}$ \\
\hline & Middle quintile & $\begin{array}{c}2.01 \\
(9.96 * *)\end{array}$ & $0.35(2.02)$ & $\begin{array}{c}11.54 * * * \\
(73.09 * * *)\end{array}$ & $\begin{array}{c}15.00 * * * \\
\left(88.43^{* * *}\right)\end{array}$ \\
\hline & Fourth quintile & $\begin{array}{c}12.10^{* * *} \\
(57.06 * * *)\end{array}$ & $\begin{array}{c}11.21 * * * \\
\left(45.40^{* * *}\right)\end{array}$ & $\begin{array}{c}12.51^{* * *} \\
\left(56.41^{* * *}\right)\end{array}$ & $\begin{array}{c}8.77 * * * \\
(38.18 * * *)\end{array}$ \\
\hline & Top quintile & $\begin{array}{c}14.04 * * * \\
(72.99 * * *)\end{array}$ & $\begin{array}{c}13.55^{* * *} \\
(74.86 * * *)\end{array}$ & $\begin{array}{c}2.21 \\
(11.47 * * *)\end{array}$ & $\begin{array}{c}2.28 \\
\left(12.71^{* * *}\right)\end{array}$ \\
\hline
\end{tabular}

Notes: Only Mantel-Haenszel test are reported. *** indicates significance at 1\%-level, ** indicates significance at $5 \%$-level, and * indicates significance at 10\%-level. Figures in parentheses are for approximated weighted tests. To allow for test calculations, weights have been divided by 1,000 and rounded. Results do not change materially if weights are divided by 10 or 100 . Using full weights exceeds computational limits of software program. "+" indicates that the combined odds for minorities in the relevant years were larger than for whites and "-" indicates that the odds for whites were greater than for minorities. Income limits for quintiles are taken from Census (2005). 
Table 9: Tests of differences between groups and over time of debt payments relative to debt

\begin{tabular}{|c|c|c|c|c|c|c|c|}
\hline \multirow{2}{*}{$\begin{array}{l}\text { Ratios to be tested } \\
\text { African-Americans/whites }\end{array}$} & \multirow{2}{*}{$\begin{array}{l}\text { Test } \\
\text { test for } 1989 / 2001\end{array}$} & \multirow{2}{*}{$\begin{array}{l}\text { Ratio } \\
++"\end{array}$} & \multicolumn{2}{|c|}{2004 to 1989} & \multirow{2}{*}{$\begin{array}{c}\text { Ratio } \\
"+"\end{array}$} & \multicolumn{2}{|c|}{2004 to 2001} \\
\hline & & & $\begin{array}{c}\text { unweighted } \\
0.01\end{array}$ & $\begin{array}{l}\text { weighted } \\
65.15^{* * *}\end{array}$ & & $\begin{array}{c}\text { unweighted } \\
6.48^{* * *}\end{array}$ & $\begin{array}{l}\text { weighted } \\
12.03^{* * *}\end{array}$ \\
\hline & test for 2004 & $"+"$ & $14.59 * * *$ & $46.46 * * *$ & "+" & $14.59 * * *$ & $46.46^{* * *}$ \\
\hline \multirow{4}{*}{ Hispanics/whites } & test for differences of differences & "+" & 0.18 & $18.37 * * *$ & "-" & $2.81^{*}$ & $10.82 * * *$ \\
\hline & test for early period & $"+"$ & 0.03 & $10.15^{* * *}$ & "+" & $4.36 * *$ & $20.72 * * *$ \\
\hline & test for late period & $"+"$ & $3.97 * *$ & $15.48 * * *$ & "+" & $3.97 * *$ & $15.48 * * *$ \\
\hline & test for differences of differences & "-" & 0.95 & $2.91^{*}$ & "-" & 0.98 & $4.53^{* *}$ \\
\hline \multirow[t]{3}{*}{ bottom quintile/top quintile } & test for early period & $"+"$ & 0.00 & $125.53 * * *$ & "+ & $19.92 * * *$ & $84.30 * * *$ \\
\hline & test for late period & $"+"$ & $7.85^{* * *}$ & $29.40 * * *$ & "+" & $7.85 * * *$ & $29.40 * * *$ \\
\hline & test for differences of differences & "+" & 0.28 & $12.93 * * *$ & "+" & 1.14 & $4.61^{* *}$ \\
\hline \multirow{3}{*}{ second quintile/top quintile } & test for early period & $"+"$ & 0.44 & $36.25 * * *$ & "-" & $39.62 * * *$ & $131.06^{* * * *}$ \\
\hline & test for late period & "+" & $33.63 * * *$ & $119.80 * * *$ & "+" & $33.63 * * *$ & $119.80 * * *$ \\
\hline & test for differences of differences & $"+"$ & 0.79 & 0.05 & "+ & 0.21 & 0.34 \\
\hline \multirow[t]{3}{*}{ middle quintile/top quintile } & test for early period & $"+"$ & 0.61 & $12.80^{* * *}$ & "+ & $19.05^{* * *}$ & $64.44 * * *$ \\
\hline & test for late period & "+" & $17.05^{* * *}$ & $57.06^{* * *}$ & "+ & $17.05^{* * *}$ & $57.06^{* * *}$ \\
\hline & test for differences of differences & $"+"$ & 0.92 & 0.12 & "+ & 0.97 & $4.85^{* *}$ \\
\hline \multirow[t]{3}{*}{ fourth quintile/top quintile } & test for early period & "-" & 0.81 & 0.01 & "+" & $10.93 * * *$ & $13.29 * * *$ \\
\hline & test for late period & "+" & $8.04 * * *$ & $18.68 * * *$ & "+ & $8.04^{* * *}$ & $18.68 * * *$ \\
\hline & test for differences of differences & "-" & 0.98 & $4.30^{* *}$ & "-" & 0.15 & 0.76 \\
\hline
\end{tabular}

Notes: All tests are adjusted Wald tests (F-tests). *** indicates significance at 1\%-level, ** indicates significance at 5\%-level, and * indicates significance at $10 \%$-level. "+" indicates that debt payments relative to debt for minorities and lower-income families are larger than for their counterparts in single years. For combined tests, "-" indicates that the difference between minority and lower-income families and their counterparts was higher in 2004 than in earlier years, while "+" indicates a narrowing gap. Income limits for quintiles are taken from Census (2005). 
Table 10: Tests of differences between groups and over time of interest rates

\begin{tabular}{|c|c|c|c|c|c|c|c|c|c|c|c|}
\hline \multirow[b]{2}{*}{ Ratios to be tested } & \multirow[b]{3}{*}{ test for $1989 / 2001$} & \multicolumn{4}{|c|}{ Mortgage rates } & \multicolumn{4}{|c|}{ Inst. credit rates } & \multirow{2}{*}{\multicolumn{2}{|c|}{$\begin{array}{c}\begin{array}{c}\text { Credit card } \\
\text { interest rates }\end{array} \\
2004 \text { to } 2001\end{array}$}} \\
\hline & & \multicolumn{2}{|c|}{2004 to 1989} & \multicolumn{2}{|c|}{2004 to 2001} & \multicolumn{2}{|c|}{2004 to 1989} & \multicolumn{2}{|c|}{2004 to 2001} & & \\
\hline African- & & $"+"$ & 1.83 & $"+"$ & $63.68 * * *$ & "+" & $5.81^{* *}$ & "+" & $6.50 * *$ & "+" & $29.82 * * *$ \\
\hline \multirow[t]{2}{*}{ Americans/whites } & test for 2004 & "+" & $96.35^{* * *}$ & "+" & $96.35^{* * *}$ & "+" & 0.69 & "+" & 0.69 & "+" & $10.31^{* * *}$ \\
\hline & test for differences of differences & "-" & $26.95^{* * *}$ & "+" & $20.89 * * *$ & "+" & 0.3 & "+" & 1.81 & "+" & 1.02 \\
\hline \multirow[t]{3}{*}{ Hispanics/whites } & test for early period & $"+"$ & $62.81^{* * *}$ & "+" & $6.17 * *$ & "+" & 2.61 & "+" & $6.88 * * *$ & "+" & $5.39 * * *$ \\
\hline & test for late period & $"+"$ & $36.35 * * *$ & "+" & $36.35 * * *$ & "+" & 0.59 & "+" & 0.59 & "+" & $20.16^{* * *}$ \\
\hline & test for differences of differences & "+" & $11.10 * * *$ & "-" & $3.57 * *$ & "-" & 0.02 & "+" & $6.46 * * *$ & "+" & 1.94 \\
\hline \multirow{3}{*}{$\begin{array}{l}\text { bottom quintile/top } \\
\text { quintile }\end{array}$} & test for early period & $"+"$ & $15.66 * * *$ & "+" & $41.48 * * *$ & "+" & $9.91 * * *$ & "+" & $4.80^{* *}$ & "+" & $67.34 * * *$ \\
\hline & test for late period & $"+"$ & $66.97 * * *$ & "+" & $66.97 * * *$ & "+" & $33.65 * * *$ & "+" & $33.65 * * *$ & "+" & $38.03^{* * *}$ \\
\hline & test for differences of differences & "-" & $4.12^{* *}$ & "-" & $13.87 * * *$ & "-" & $16.03^{* * *}$ & "-" & $10.33^{* * *}$ & "+" & 0.06 \\
\hline \multirow{3}{*}{$\begin{array}{l}\text { second quintile/top } \\
\text { quintile }\end{array}$} & test for early period & $"+"$ & $30.00 * * *$ & "+" & $65.76^{* * *}$ & "+" & $13.99 * * *$ & "+" & $7.63 * * *$ & "+" & $18.49 * * *$ \\
\hline & test for late period & "+" & $187.35^{* * *}$ & "+" & $187.35^{* * *}$ & "+" & $30.95 * * *$ & "+" & $30.95 * * *$ & "+" & $57.85 * * *$ \\
\hline & test for differences of differences & "-" & $18.19 * * *$ & "-" & $39.16^{* * *}$ & "-" & $12.69 * * *$ & "-" & 1.67 & "+" & $8.96^{* * *}$ \\
\hline \multirow{3}{*}{$\begin{array}{l}\text { middle quintile/top } \\
\text { quintile }\end{array}$} & test for early period & "-" & 0.24 & "+" & $74.67 * * *$ & "+" & $8.31 * * *$ & "+" & $25.19 * * *$ & "-" & 0.18 \\
\hline & test for late period & "+" & $215.71^{* * *}$ & "+" & $215.71^{* * *}$ & "+" & $5.91^{* *}$ & "+" & $5.91^{* *}$ & "+" & $44.14^{* * *}$ \\
\hline & test for differences of differences & "-" & $65.94 * * *$ & "-" & $22.15^{* * *}$ & "+" & 0.57 & "+" & $3.64^{*}$ & "-" & $26.57 * * *$ \\
\hline \multirow{3}{*}{$\begin{array}{l}\text { fourth quintile/top } \\
\text { quintile }\end{array}$} & test for early period & $"+"$ & $15.26 * * *$ & "+" & $57.94 * * *$ & "+" & 0.55 & "+" & $27.68 * * *$ & "-" & $22.79 * * *$ \\
\hline & test for late period & "+" & $98.05^{* * *}$ & "+" & $98.05 * * *$ & "+" & $4.15^{* *}$ & "+" & $4.15^{* *}$ & "+" & $6.57 * * *$ \\
\hline & test for differences of differences & "-" & $5.37 * *$ & "-" & $7.56^{* * *}$ & "+" & $4.67^{* *}$ & "+" & $3.44^{*}$ & "-" & $26.33^{* * *}$ \\
\hline
\end{tabular}

Notes: All tests are adjusted Wald tests (F-tests). All results are for weighted data. *** indicates significance at 1\%-level, ** indicates significance at 5\%-level, and * indicates significance at 10\%-level. "+" indicates that debt payments relative to debt for minorities and lower-income families are larger than for their counterparts in single years For combined tests, "+" indicates that the difference between minority and lower-income families and their counterparts was higher in 2004 than in earlier years. Income limits for quintiles are taken from Census (2005). 
Table 12: Tests of differences between groups and over time of sources of loans

\begin{tabular}{|c|c|c|c|c|c|c|c|c|c|c|c|c|c|}
\hline & & \multicolumn{4}{|c|}{ Traditional banks } & \multicolumn{4}{|c|}{ Consumer banks } & \multicolumn{4}{|c|}{ Credit unions } \\
\hline & & \multicolumn{2}{|c|}{2004 to 1989} & \multicolumn{2}{|c|}{2004 to 2001} & \multicolumn{2}{|c|}{2004 to 1989} & \multicolumn{2}{|c|}{2004 to 2001} & \multicolumn{2}{|c|}{2004 to 1989} & \multicolumn{2}{|c|}{2004 to 2001} \\
\hline \multirow{3}{*}{$\begin{array}{l}\text { African- } \\
\text { Americans/whites }\end{array}$} & 1989/2001 & "-" & $77.72 * * *$ & "-" & $95.05^{* * *}$ & "+" & $48.64 * * *$ & "+" & $125.20 * * *$ & "+" & 0.75 & "-" & $17.43^{* * *}$ \\
\hline & 2004 & "-" & $83.44^{* * *}$ & "-" & $83.44 * * *$ & "+" & $55.74 * * *$ & "+" & $55.74 * * *$ & "-" & 0.96 & "-" & 0.96 \\
\hline & Diff. of diff. & "+" & 2.09 & "+" & 0.17 & "+" & 2.38 & "+" & $7.95 * * *$ & "-" & 1.66 & "+" & $4.89 * *$ \\
\hline \multirow[t]{3}{*}{ Hispanics/whites } & 1989/2001 & "-" & $37.50 * * *$ & "-" & $74.07 * * *$ & "+" & $6.55 * * *$ & "+" & $62.54 * * *$ & "-" & $55.06 * * *$ & "-" & $73.65 * * *$ \\
\hline & 2004 & "-" & $65.79 * * *$ & "-" & $65.79 * * *$ & "+" & $80.63 * * *$ & "+" & $80.63 * * *$ & "-" & $23.75^{* * *}$ & "-" & $23.75 * * *$ \\
\hline & Diff. of diff. & "+" & 0.45 & "+" & 0.74 & "-" & $6.90 * * *$ & "-" & 0.05 & "+" & 1.08 & "+" & $10.16^{* * *}$ \\
\hline \multirow{3}{*}{$\begin{array}{l}\text { bottom quintile/top } \\
\text { quintile }\end{array}$} & 1989/2001 & "-" & $558.32 * * *$ & "-" & $1379.03 * * *$ & "+" & $93.94 * * *$ & "+" & $700.88^{* * *}$ & "-" & $66.89 * * *$ & "-" & 1.69 \\
\hline & 2004 & "-" & $994.48^{* * *}$ & "-" & $994.48 * * *$ & "+" & $430.24 * * *$ & "+" & $430.24 * * *$ & "-" & 0.91 & "-" & 0.91 \\
\hline & Diff. of diff. & "+" & $3.59 *$ & "+" & $10.46 * * *$ & "-" & $28.59 * * *$ & "+" & $17.03 * * *$ & "+" & $19.39 * * *$ & "+" & 0.07 \\
\hline \multirow{3}{*}{$\begin{array}{l}\text { second quintile/top } \\
\text { quintile }\end{array}$} & 1989/2001 & "-" & $224.28 * * *$ & "-" & $1016.35^{* * *}$ & "+" & $95.25 * * *$ & "+" & $631.18 * * *$ & "-" & 2.35 & "+" & $14.52 * * *$ \\
\hline & 2004 & "-" & $747.53 * * *$ & "-" & $747.53 * * *$ & "+" & $406.13^{* * *}$ & "+" & $406.13^{* * *}$ & "+" & $15.65 * * *$ & "+" & $15.65^{* * *}$ \\
\hline & Diff. of diff. & "-" & $14.91 * * *$ & "+" & $7.80 * * *$ & "-" & $14.37 * * *$ & "+" & $12.29 * * *$ & "+" & $13.32 * * *$ & "+" & 0.02 \\
\hline \multirow{3}{*}{$\begin{array}{l}\text { middle quintile/top } \\
\text { quintile }\end{array}$} & 1989/2001 & "-" & $125.37 * * *$ & "-" & $407.75^{* * *}$ & "+" & $114.41^{* * *}$ & "+" & $359.89 * * *$ & "+" & 0.39 & "+" & $36.87 * * *$ \\
\hline & 2004 & "-" & $317.48^{* * *}$ & "-" & $317.48 * * *$ & "+" & $313.68 * * *$ & "+" & $313.68 * * *$ & "+" & $7.39 * * *$ & "+" & $7.39 * * *$ \\
\hline & Diff. of diff. & "-" & 0.51 & "+" & $5.66^{* *}$ & "-" & 0.14 & "+" & 2.31 & "+" & 1.36 & "+" & $9.65 * * *$ \\
\hline \multirow{3}{*}{$\begin{array}{l}\text { fourth quintile/top } \\
\text { quintile }\end{array}$} & 1989/2001 & "-" & $48.35^{* * *}$ & "-" & $150.20 * * *$ & "+" & $44.51 * * *$ & "+" & $147.15^{* * *}$ & "+" & 1.74 & "+" & $24.18 * * *$ \\
\hline & 2004 & "-" & $81.12 * * *$ & "-" & $81.12^{* * *}$ & "+" & $120.10^{* * *}$ & "+" & $120.10^{* * *}$ & "+" & 2.34 & "+" & 2.34 \\
\hline & Diff. of diff. & "-" & 0.19 & $"+"$ & $7.75^{* * *}$ & "-" & 0.21 & "+" & 1.35 & "+" & 0.00 & "+" & $8.28 * * *$ \\
\hline
\end{tabular}

Notes: All tests are adjusted Wald tests (F-tests). All results are for weighted data. *** indicates significance at 1\%-level, ** indicates significance at 5\%-level, and * indicates significance at $10 \%$-level. "+" indicates that the loan share originating from a particular source relative to total debt for minorities and lowerincome families are larger than for their counterparts in single years. For combined tests, "+" indicates that the difference between minority and lower-income families and their counterparts was smaller in 2004 than in earlier years and "-" shows that the difference has widened over time. Income limits for quintiles are taken from Census (2005). 
Table 13: Tests of differences between groups and over time of types of loans

\begin{tabular}{|c|c|c|c|c|c|c|c|c|c|c|c|c|c|}
\hline & & \multicolumn{4}{|c|}{ Mortgages } & \multicolumn{4}{|c|}{ Installment loans } & \multicolumn{4}{|c|}{ Credit card debt } \\
\hline \multirow{4}{*}{$\begin{array}{l}\text { African- } \\
\text { Americans/whites }\end{array}$} & Test for & \multicolumn{2}{|c|}{2004 to 1989} & \multicolumn{2}{|c|}{2004 to 2001} & \multicolumn{2}{|c|}{2004 to 1989} & \multicolumn{2}{|c|}{2004 to 2001} & \multicolumn{2}{|c|}{2004 to 1989} & \multicolumn{2}{|c|}{2004 to 2001} \\
\hline & 1989/2001 & "-" & $146.76 * * *$ & "-" & $129.22 * * *$ & "+" & $106.37 * * *$ & "+" & $51.58 * * *$ & "+ & $16.92 * * *$ & "+" & $82.89 * * *$ \\
\hline & 2004 & "-" & $116.16 * * *$ & "-" & $116.16^{* * *}$ & $"+"$ & $96.98 * * *$ & $"+"$ & $96.98 * * *$ & $"+"$ & $10.72 * * *$ & $"+"$ & $10.72 * * *$ \\
\hline & Diff. of diff. & "-" & $6.18^{* *}$ & "-" & 0.05 & "-" & $9.62 * * *$ & $"+"$ & $4.04^{* *}$ & "-" & $3.25 *$ & "-" & $21.19 * * *$ \\
\hline \multirow[t]{3}{*}{ Hispanics/whites } & 1989/2001 & "-" & $27.31^{* * *}$ & "-" & $83.19 * * *$ & "+" & $19.61^{* * *}$ & "+" & $20.69 * * *$ & $"+"$ & 0.97 & "+" & $49.73 * * *$ \\
\hline & 2004 & "-" & $87.71^{* * *}$ & "-" & $87.71^{* * *}$ & "+" & $19.71 * * *$ & $"+"$ & $19.71 * * *$ & $"+"$ & $30.64 * * *$ & "+" & $30.64 * * *$ \\
\hline & Diff. of diff. & "+" & 0.67 & "-" & 0.15 & "-" & $3.03 *$ & "-" & 0.24 & "+" & $4.42 * *$ & "-" & 2.32 \\
\hline \multirow{3}{*}{$\begin{array}{l}\text { bottom quintile/top } \\
\text { quintile }\end{array}$} & 1989/2001 & "-" & $1158.60 * * *$ & "-" & $1612.74 * * *$ & "+" & $653.21 * * *$ & "+" & $355.50 * * *$ & "+" & $110.97 * * *$ & "+" & $598.31^{* * *}$ \\
\hline & 2004 & "-" & $1284.52 * * *$ & "-" & $1284.52^{* * *}$ & "+" & $535.15^{* * *}$ & $"+"$ & $535.15^{* * *}$ & "+" & $409.17 * * *$ & "+" & $409.17^{* * *}$ \\
\hline & Diff. of diff. & "-" & 1.46 & "-" & $4.57 * *$ & "-" & $42.91 * * *$ & "-" & $16.16^{* * *}$ & "+" & $26.94 * * *$ & "-" & $11.78^{* * *}$ \\
\hline \multirow{3}{*}{$\begin{array}{l}\text { second quintile/top } \\
\text { quintile }\end{array}$} & 1989/2001 & "-" & $308.75 * * *$ & "-" & $1343.43^{* * *}$ & "+" & $283.17 * * *$ & "+" & 691.37*** & "+" & $86.42^{* * *}$ & "+" & $472.18 * * *$ \\
\hline & 2004 & "-" & $974.23 * * *$ & "-" & $974.23 * * *$ & $"+"$ & $530.84 * * *$ & $"+"$ & $530.84 * * *$ & "+" & $331.36 * * *$ & $"+"$ & $331.36 * * *$ \\
\hline & Diff. of diff. & "+" & $20.08 * * *$ & "-" & $10.01^{* * *}$ & "-" & 0.30 & "-" & $5.25^{* *}$ & "+" & $11.66^{* * *}$ & "-" & $4.76^{* *}$ \\
\hline \multirow{3}{*}{$\begin{array}{l}\text { middle quintile/top } \\
\text { quintile }\end{array}$} & 1989/2001 & "-" & 206.70*** & "-" & $577.57 * * *$ & "+" & $248.49 * * *$ & "+" & $452.95 * * *$ & "+" & $76.09 * * *$ & "+" & $267.79 * * *$ \\
\hline & 2004 & "-" & $383.75 * * *$ & "-" & 383.75*** & "+" & $388.37 * * *$ & "+" & $388.37 * * *$ & "+" & $180.99 * * *$ & "+" & $180.99 * * *$ \\
\hline & Diff. of diff. & "-" & 1.14 & "-" & $17.27 * * *$ & "+" & $11.42^{* * *}$ & "-" & $5.07 * *$ & "-" & 0.24 & "-" & $5.74 * *$ \\
\hline \multirow{3}{*}{$\begin{array}{l}\text { fourth quintile/top } \\
\text { quintile }\end{array}$} & 1989/2001 & "-" & $31.61^{* * *}$ & "-" & $137.00 * * *$ & "+" & $128.89 * * *$ & "+" & 167.19*** & "+" & $18.75^{* * *}$ & "+" & $72.23 * * *$ \\
\hline & 2004 & "-" & $86.16^{* * *}$ & "-" & $86.16^{* * *}$ & "+" & $188.11^{* * *}$ & "+" & $188.11^{* * *}$ & "+" & $56.30 * * *$ & "+" & $56.30 * * *$ \\
\hline & Diff. of diff. & "+" & 0.35 & "-" & $4.79 * *$ & "-" & $4.63^{* *}$ & "-" & 0.09 & "+" & 0.56 & "-" & 0.46 \\
\hline
\end{tabular}

Notes: All tests are adjusted Wald tests (F-tests). All results are for weighted data. *** indicates significance at 1\%-level, ** indicates significance at 5\%-level, and * indicates significance at 10\%-level. "+" indicates that the loan share originating from a particular source relative to total debt for minorities and lowerincome families are larger than for their counterparts in single years. For combined tests, "+" indicates that the difference between minority and lower-income families and their counterparts was higher in 2004 than in earlier years. Income limits for quintiles are taken from Census (2005). 


\section{References:}

Akhigbe, A., and Madura, J., 2004, Bank Acquisitions of Security Firms: The Early Evidence, Applied Financial Economics 14, No. 7: 485-496.

Akhigbe, A., Madura, J., and Whyte, A.M., 2004, Partial Anticipation and the Gains to Bank Merger Targets, Journal of Financial Services Research 26, No.1: 55.71.

Al Mamun, A., Hassan, M.K., Karels, G.V., and Maroney, N., 2005, Financial Services Modernization Act of 1999: Market Assessment of Winners and Losers in the Insurance Industry, Journal of Insurance Issues 28, No.1: 103-128.

Ausubel, L. (1997) Credit card defaults, credit card profits, and bankruptcy, American Bankruptcy Law Journal, 71, pp. 249-270.

Avery, R.B., and Samolyk, K.A., 2004, Bank Consolidation and Small Business Lending: The Role of Community Banks, Journal of Financial Services Research 25, No. 2-3:291325.

Barr, M., 2001, Five Opportunities for the Bush Administration and the 107th Congress, Washington, D.C.: Brookings Institution Center on Urban and Metropolitan Policy.

Bates, T., 2000, Financing the Development of Urban Minority Communities: Lessons of History, Economic Development Quarterly 14, No.3:227-41.

Berger, A.N., 2003, The Economic Effects of Technological Progress: Evidence from the Banking Industry, Journal of Money, Credit and Banking 35, No.2:141-176.

Bird, E. J., Hagstrom, P.A. \& Wild, R. (1999) Credit card debts of the poor: high and rising, Journal of Policy Analysis and Management, 18 (1), pp. 125-33.

Black, S. \& Morgan, D., 1999, Meet the new borrowers, Current Issues in Economics and Finance, 5(3), pp. 1-6.

Blanchflower, D.G., Levine, P.B., and Zimmerman, D.J., 2003, Discrimination in the Small-Business Credit Market, Review of Economics and Statistics 85, No.4:930-943.

Bloemen, H.G. and Stancanelli, E.G.F., 2005, Financial Wealth, Consumption Smoothing and Income Shocks Arising from Job Loss, Economica Vol.72, No. 287:431-52.

Bocian, D., Ernst, K., and Li, W., 2006, Unfair Lending: The Effect of Race and Ethnicity on the Price of Subprime Mortgages, Durham, NC: Center for Responsible Lending.

Bostic, R., Mehren, H., Paulson, A., and Saidenberg, M., 2002, Regulatory Incentives and Consolidation: The Case of Commercial Bank Mergers and the Community 
Reinvestment Act, Federal Reserve Bank of Chicago, Working Paper Series WP-02-06, Chicago, IL: Federal Reserve Bank of Chicago.

Canner, G.B., Passmore, W., and Smith, D., 1994, Residential Lending to Low-income and Minority Families: Evidence from the 1992 HMDA Data, Federal Reserve Bulletin 80, No.2: 79-109.

Carow, K.A., Kane, E.J., and Narayanan, R.P., 2006, How Have Borrowers Fared in Banking Megamergers?, Journal of Money, Credit and Banking 38, No.3: 821-836.

Cavalluzzo, K.S., and Cavalluzzo, L.C., 1998, Market Structure and Discrimination: The Case of Small Businesses, Journal of Money, Credit, and Banking 30, No.4: 771-792.

Cavalluzzo, K.S., Cavalluzzo, L.C., and Wolken, J.D., 2002, Competition, Small Business Financing, and Discrimination: Evidence from a New Survey, Journal of Business 75, No.4:641-76.

Cavalluzzo, K. and Wolken, J., 2005, Small Business Loan Turndowns, Personal Wealth, and Discrimination, Journal of Business 78, No.6: 2153-2177.

Center for Responsible Lending, 2006, Financial Quicksand: Payday Lending Sinks Borrowers in Debt with $\$ 4.2$ billion in Predatory Fees Every Year, Durham, NC: CRL.

Center for Responsible Lending, 2005, Race Matters: The Concentration of Payday Lenders in African-American Neighborhoods in North Carolina, Durham, NC: CRL.

Chakravarty, S., 2002, Relationships and Rationing in Consumer Loans: Evidence from the Nineties, Purdue University, Purdue, IN, Department of Economics, Working Paper No. 38.

Choudhury, S., 2002, Racial and Ethnic Differences in Wealth and Asset Choices, Social Security Bulletin 64, No.4: 1-15.

Consumer Federation of America, 1998, The Growth of Legal Loan Sharking: A Report on the Payday Loan Industry, Washington, D.C.: Consumer Federation of America.

Consumer Federation of America, 1999, Safe Harbor for Usury: Recent Developments in Payday Lending, Washington, D.C.: Consumer Federation of America.

Consumer Union, 2003, Payday Lenders Burden Working Families and the U.S. Armed Forces, Washington, DC: CU.

Crook, J., 1996, Credit Constraints and US Families, Applied Financial Economics 6:477-485. 
Duby, J., Halperin, E., and James, L., 2005, High Cost and Hidden From View: The $\$ 10$ Billion Overdraft Loan Market, CRL Issue Paper No. 9, Durham, NC: Center for Responsible Lending.

Dymski, G.A., 2001, Is Discrimination Disappearing? Residential Credit Market Evidence, 1992-98, International Journal of Social Economics 28, No.10-11-12:10251045.

Ely, D.P., and Robinson, K.J., 2001, Consolidation, Technology, and the Changing Structure of Bank’s Small Business Lending, Federal Reserve Bank of Dallas Economic and Financial Review, $1^{\text {st }}$ Quarter:23-32.

Emmons, W.R. and Schmid, F.A., 2000, Bank Competition and Concentration: Do Credit Unions Matter? Federal Reserve Bank of St. Louis Review 82, No.3:29-42.

Feinberg, R.M., 2001, The Competitive Role of Credit Unions in Small Local Financial Services Markets, Review of Economics and Statistics 83, No.3: 560-563.

Feinberg, R.M., and Rahman A.F.M.A., 2001, A Causality Test of the Relationship between Bank and Credit Union Lending Rates in Local Markets, Economics Letters 71, No.2: 271-275.

Finke, M., Huston, S., Siman, E., and Corlija, M., 2005, Characteristics of Recent Adjustable-Rate Mortgage Borrowers, Financial Counseling and Planning 16, No.2:1728.

Fishbein, A., and Woodall, P., 2006, Subprime Locations: Patterns of Geographic Disparity in Subprime Lending, Washington, DC: Consumer Federation of America.

Fox, J.A., and Guy, E., 2005, Driven into Debt: CFA Car Title Loan Store and Online Survey, Washington, DC: Consumer Federation of America.

Fox., L., and Hoffman, J., 2004, Federal Reserve Personal Financial Education Initiatives, Federal Reserve Bulletin 90, No.4: 447-457.

Gabriel, S.A., and Rosenthal, S.S., 1991, Credit Rationing, Race, and the Mortgage Market, Journal of Urban Economics 29, No.3: 371-379.

Goddard, J.A., McKillop, D.G., and Wilson, J.O.S., 2002, The Growth of US Credit Unions, Journal of Banking and Finance 26, No.12:2327-2356.

Graves, S., and Peterson, C.L., 2005, Predatory Lending and the Military: The Law and Geography of "Payday" Loans in Military Towns, unpublished manuscript, University of Florida, College of Law, Gainesville, FL. 
Hein, S.E., Koch, T.W., and MacDonald, S.S., 2005, On the Uniqueness of Community Banks, Federal Reserve Bank of Atlanta Economic Review 90, No.2:15-36.

Hilgert, M.A., Hogarth, J.M., and Beverly, S.G., 2003, Household Financial Management: The Connection between Knowledge and Behavior, Federal Reserve Bulletin 89, No.7:309-322.

Holloway, S.R., and Wyly, E.K., 2001, “The Color of Money” Expanded: Geographically Contingent Mortgage Lending in Atlanta, Journal of Housing Research 12, No.1:55-90.

James, L. and Smith, P., 2006, Overdraft Loans: Survey Finds Growing Problems for Consumers, CRL Issue Paper No. 13, Durham, NC: Center for Responsible Lending.

Kaushik, S.K., and Lopez, R.H., 1994, The Structure and Growth of the Credit Union Industry in the United States: Meeting Challenges of the Market, American Journal of Economics and Sociology 53, No.2: 219-243.

Krueger, D., and Perri, F., 2005, Understanding Consumption Smoothing: Evidence from the U.S. Consumer Expenditure Data, Journal of the European Economic Association, Vol. 3, No. 2-3:340-49.

Krueger, D., and Perri, F., 2002, Does Income Inequality Lead to Consumption Inequality? Evidence and Theory, NBER Working Paper No. 9202, Cambridge, MA: National Bureau of Economic Research.

Leggett, K.J., and Strand, R.W., 2002, Membership Growth, Multiple Membership Groups and Agency Control at Credit Unions, Review of Financial Economics 11, No.1: 37-46.

Lyons, A.C., 2003, How Credit Access Has Changed Over Time for U.S. Families, Journal of Consumer Affairs 37, No.2:231-255.

Lyons, A.C., Chang, Y., and Scherpf, E.M., 2006, Translating Financial Education into Behavior Change for Low-Income Populations, Financial Counseling and Planning 17, No.2:27-45.

Lyons,A.C., Palmer, L., and Jayaratne, K.S.U., and Scherpf, E., 2006, Are We Making the Grade? A National Overview of Financial Education and Program Evaluation, Journal of Consumer Affairs 40, No.2:208-235.

Lyons, A.C., and Scherpf, E., 2004, Moving from Unbanked to Banked: Evidence from Money Smart Program, Financial Services Review 13, No.3: 215-31.

Manning, R., 2000, Credit Card Nation: The Consequences of America's Addiction to Credit, New York: Basic Books. 
Munnell, A., Browne, L.E., and McEneaney, J., 1996, Mortgage Lending in Boston: Interpreting the HMDA Data, American Economic Review 86, No1: 25-53.

Newman, K., and Wyly, E.K., 2004, Geographies of Mortgage Market Segmentation: The Case of Essex County, New Jersey, Housing Studies 19, No.1: 83-83.

Rauch, J.H., and Hendrickson, J.M., 2004, Does Bank Consolidation Hurt the Small Business Borrower?, Small Business Economics 23, No.3:219-226.

Rhoades, S.A., Bank Mergers and Banking Structure in the U.S., 1980-1998, Staff Study No. 174, Washington, D.C.: Board of Governors, Federal Reserve System.

Rose, J.T., 1993, Interstate Banking, Bank Consolidation, and Bank Lending to Small Business, Small Business Economics 5, No3:197-206.

Ross, S., 2005, The Continuing Practice and Impact of Discrimination, University of Connecticut, Storrs, CT, Department of Economics Working Paper No. 19.

Schug, M.C., Niederjohn, M.S., and Wood, W.C., 2006, Your Credit Counts Challenge: A Model Program for Financial Education for Low and Moderate Income Adults, Journal of Private Enterprise 21, No.2: 196-208.

Stavins, J. (2000) Credit card borrowing, delinquency, and personal bankruptcy, New England Economic Review, July/August, pp. 15-30.

Stegman, M.A. and Faris, R., 2003, Payday lending: A business model that encourages chronic borrowing, Economic Development Quarterly, 17 (1), pp. 8-32.

Stiglitz, J., and Weiss, A., 1981, Credit Rationing in Markets with Imperfect Information, American Economic Review, 71, No.3: 393-410.

Tanik, O., 2005, Payday Lenders Target the Military, CRL Issue Paper No. 11, Durham, NC: Center for Responsible Lending.

Tripp, J.D., and Smith, S.D., 1993, U.S. Credit Union Motivation for Involvement in the First-Mortgage Market, Journal of Real Estate Finance and Economics 7, No.3:229-236.

U.S. Census Bureau, 2006, American Housing Survey 2005, Washington, DC: Census.

U.S. Census Bureau, 2005, Income, Poverty, and Health Insurance Coverage in the United States: 2004; Washington, DC: Census.

U.S. Department of Defense, 2006, Report on Predatory Lending Practices Directed at Members of the Armed Forces and their Families, Washington, DC: DOD. 
Weinberg, J.A., Borrowing by U.S. Families, Federal Reserve Bank of Richmond Economic Quarterly 92, No.3:177-194.

Weller, C., 2006, The End of the Great American Housing Boom, CAP Economic Policy Report, Washington, DC: Center for American Progress

Weller, C., and Douglas, D., 2007, One Nation Under Debt, Challenge, Vol. 50, No.1: 54-75.

Westrich, T., and Bush, M., 2005, Blindfolded into Debt: A Comparison of Credit Card Costs and Conditions at Banks and Credit Unions, Chicago, IL: Woodstock Institute.

Wheelock, D.C., and Wilson, P.W., 2004, Consolidation in US Banking: Which Banks Engage in Mergers?, Review of Financial Economics 13, No.1-2:7-39.

White, L., 2002, Financial Modernization after Gramm-Leach-Bliley: What About Communities?, New York University, Leondard N. Stern School of Business, Department of Economics, Working Paper No. 02-02.

Wyly, E.K., and Hammel, D.J., Gentrification, Segregation, and Discrimination in the American Urban System, Environment and Planning 36, No.7:1215-1241.

Yao, R., Gutter, M.S., and Hanna, S.D., 2005, The Financial Risk Tolerance of Blacks, Hispanics, and Whites, Financial Counseling and Planning 16, No.1:51-62.

Yildirim, H.S., Kwag, S.W., and Collins, M., 2006, An Examination of Equity Market Response to the Gramm-Leach-Bliley Act Across Commercial Banking, Investment Banking, and Insurance Firms, Journal of Business Finance \& Accounting 33, No. 9-10: 1629-1649.

Yoo, P. (1996) Charging up a mountain of debt: families and their credit cards, Federal Reserve Bank of St. Louis Working Paper \#96-015A. 